\title{
THE SOCIAL VICE OF ACCIDENT INDEMNITY
}

\section{Herbert D. Laube $\dagger$}

The automobile is more deadly than war. ${ }^{1}$ It is more fatal than earthquakes ${ }^{2}$ in Italy, the classic home of the earthquake. It is deadlier than the five worst infectious diseases combined. ${ }^{3}$ The toll of lives claimed by the automobile in the United States in 1930 was estimated to be 32,500 . In the same year, more than 960,000 persons suffered from non-fatal injuries. ${ }^{4}$ American hospitals spend $\$ 70,000,000$ annually caring for the victims of automobile accidents, who are without funds. ${ }^{5}$ The automobile has deprived thousands of women and children of their support and left them dependent widows and orphans. ${ }^{6}$ It has produced an annual national economic loss estimated approximately at a billion dollars. ${ }^{7}$ However extravagant or inaccurate these observations may be, if they have a substantial basis, then one must readily concede that such a situation constitutes one of our major social problems. ${ }^{8}$

An advocate of compulsory automobile insurance has said that the law now furnishes in case of accident only one method for securing compensation-a lawsuit.

"And any one who brings a suit finds himself forthwith enshrouded in a cloud of difficulties. It is interesting, it is pathetic, it is tragic to see how these difficulties pile themselves up to obstruct the plaintiff's progress and the prompt and certain attainment of any just result." 9

† B. L., 1903, University of Wisconsin; A. M., IgrI, University of Michigan; LL. B., 19r6, Columbia University; S. J. D., I924, Harvard University; Professor of Law, Corneli University Law School; member of the American Bar Association, the American Academy of Political and Social Science and the American Judicature Society.

${ }^{2}$ The Motor More Deadly Than War (Aug. 27, I927) 94 LIr. Dig. I2.

"Earthquakes Less Fatal Than Autos (Nov. I, 1930) I07 IIr. Dig. 30.

${ }^{3}$ Autombile Fatalities Becoming One of Our Deadliest Scourges (I926) 35 AM. Ciry $34 \mathrm{I}$.

- Worse Than War (I93I) 3; Accident Facts (I93I) 5. C. W. Galloway, VicePresident of B. \& O. Ry., says, "In the ten years I920 to I929, inclusive, on all railroads in the United States, there were 579 passengers killed, and having in mind that there are more persons injured than killed in railroad accidents, if we take the total number of passenger casualties on all railroads in the United States in the last ten years to which I have referred, we have 22,854." (April 24, I930) Address before the Associated Traffic Clubs of America, 2.

'How Many People Will Automobiles Kill in I930 (Mar. 22, I930) 104 Lir. Drg. 49.

- Chaplin, Compensation for Street Accidents (r925) 54 Survey 526; $A$ Word for Compulsory Motor Insurance (Mar. 24, I923) 76 LiT. Dig. 62.

${ }^{3} 31,000$ More Killed in Our Motor Massacre (June I4, 1930) I05 LrT. Drg. Ir; Slauson, The Auto's Toll of Lives (1925) I32 Scr. AMr. 152.

The Murderous Motor (1925) 47 New ReP. I89; Deak, Automobile Accidents: A Comparative Study of the Law of Liability in Europe (193I) 79 U. OF PA. L. REv. 27I, 272.

${ }^{\circ}$ Chaplin, op. cit. supra note 6. 
There should be a remedy for "this nightmare of complication, confusion, delay, extravagance and injustice" against which he protests. Another advocate complains ${ }^{10}$ that in case of automobile accidents resulting in personal injury, insurance has taken a "peculiar form" which does not furnish adequate protection either for the community or for the car-owner. This thesis is primarily concerned with the judicial interpretation of the "peculiar form" of the insurance policy which disappointed this advocate's expectations and which enshrouded the plaintiff in a "cloud of difficulties." The ever-growing field of statute law, providing for the financial responsibility of the owners and operators of motor vehicles, has been characterized as a significant legislative contribution to the growth of the law. Such a need has been declared to be due to the inability of the machinery of the common law, which was fashioned to meet the needs of a past era, to cope with this problem. ${ }^{11}$ The indemnity policy is mentioned as a notable obstacle, which frequently defeated the victim in recovering compensation for his injuries. A careful review of the decisions reveals that it was not so much the inability of the common law to cope with this problem as it was the inability of the judges, ${ }^{12}$ whose archaic reverence for a mediæval conception obscured their vision. Commitment of the courts to an outworn policy may be too firm to be broken by the tools of the judicial process, ${ }^{13}$ but it does not excuse the intellectual blindness of the courts to the interest of society in the physical integrity of the individual victimized by accident.

\section{Is Indemnity a Gaming Contract?}

No man should be allowed to bargain for an advantage to arise upon the destruction of life or property, for that is to wager. ${ }^{14}$ The chief objection to a wagering contract is that it leads to unearned gain. Unearned gain has harmful social consequences..$^{15}$ If one takes out a policy of insurance upon the life of a person in whom he has no interest whatever, his risk is created by the contract itself. It is a wagering or gambling contract. $^{16}$ An insurable interest is necessary to the validity of a policy of insurance. The object of insurance is not to make a possible gain but to avert a possible loss. A policy without such an interest has nothing in

${ }^{10}$ Compensation for Accidents (1927) 52 NEW REP. II2.

$"$ Note (1930) 30 Cor. L. Rev. I09.

22 "Surely every loyal, thinking person in our political community must deplore undue criticism of the great common law which so wisely regulates every consequential act of our lives, from the cradle to the grave. But there is reason to think that the common law in this instance is not so defective as supposed, and the fault lies with the unreasoned adjudications of inferior courts." In re Kathan's Will, I4I N. Y. Supp. 705, 707 (1913).

${ }^{23}$ Cardozo, Paradoxes of the Legal Sctentce (1928) 64.

11 Thomas, Mortgages (3d ed. I9I4) 460.

${ }^{25}$ Patterson, Insurable Interest in Life (IgI8) I8 CoL. L. REv. 38I, 386.

${ }^{19}$ Cooley, Briefs on Insurance (2d ed. 1927) 333. 
common with insurance except in name and form. It is a species of gaming, pregnant with mischief. ${ }^{17}$

In discussing the validity of a policy of insurance to indemnify against damages for personal injury by accident in the operation of an automobile, the Pennsylvania court has said:

"There was a time when all insurance, and especially of life, was looked upon with suspicion and disfavor, but it was only because regarded as a species of wagering contract. That time has gone by. And with the intelligent study of political economy bringing the recognition of the fact that even the most apparently disconnected and sporadic occurrences are subject to at least an approximate law of averages, the insurance against loss from any such occurrence has been recognized as a legitimate subject of protection to the individual by a guaranty of indemnity from some party undertaking to distribute and divide the loss among a number of others for a premium giving them a prospect of profit."18

Such contracts of indemnity are distinguished from gaming contracts because they create no inducement or temptation to commit fraud or crime even though there is great disparity between the consideration paid and the indemnity received by the insured. ${ }^{19}$ According to Professor Vance, the gambling contract is based upon an event in which the assured has no interest other than the payment of the wager. "The gambler courts fortune; the insured seeks to avoid misfortune." 20 An indemnity contract is primarily a contract of investment. However, when the contract steps beyond indemnity, it becomes obnoxious as a wagering policy. ${ }^{21}$

In the light of these generally accepted pronouncements, let us examine the decision in Kinnan v. Fidelity \& Casualty Co. ${ }^{22}$ In that case, the plaintiff, an employee, sued his employer to recover damages for personal injuries and he obtained a judgment for $\$ \mathrm{I} 500$. Before judgment was entered and during the pendency of a motion for a new trial, the defendantemployer released his indemnitor for $\$ 1000$ and immediately left the state. But, he left no property behind him out of which to satisfy the judgment. By the settlement, the indemnitor was richer by $\$ 500$ and the insured by $\$ 1000$. Broadly, the question was whether it was legal for the Casualty Company and the insured to traffic in the miseries of their victim. Action was brought by the employee to recover from the indemnitor the amount

${ }^{17}$ Pritchet v. Insurance Co. of N. America, 3 Yeates 458, 464 (Pa. I803).

${ }^{18}$ Gould v. Brock, 22r Pa. 38, 40, 69 Atl. Ir22 (Ig08).

${ }^{10}$ CoOLEy, op. cit. supra note 16 , at 202.

${ }^{20}$ VANCE, INSURANCE (2d ed. 1930) 66, 123.

noven v. Employers' Liability Assurance Corp., 93 Wis. 20I, 204, 67 N. W. 46, 47 (1896).

$=107$ I11. App. 406, 410 (1903). 
of his judgment. Relief was denied to the injured employee because it did not appear that the settlement was not made in good faith.

Whether it was made in good faith or not, both parties had profited by the misfortune of their victim. The question of good faith was irrelevant. The court's decision clearly made it a wagering contract, if the contract is to be judged by the result. This case illustrates that, under indemnity contracts, the injured person receives very little consideration either from the contract or from the court. ${ }^{23}$ The burden of death and injury is borne by the crippled or by the dependents of the victim of the accident. The stockholders of the accident companies and the reckless insured take the profits and the victim and his family are left to the care of charity. ${ }^{24}$ Nothing would seem more clear than the fact that indemnity in case of injuries from accident is the most vicious form of gambling unless the assets of the policy or their equivalent are appropriated to the payment of the claim of the injured victim. As late as I924, an Illinois court declared that "No question of public policy is involved" in a policy of indemnity against loss from accident. ${ }^{25}$ Yet, in 1923 , the year before the decision, there were bills pending in the legislatures of twenty-four states in response to a demand for compulsory automobile insurance. ${ }^{20}$ The court assumed that because an Illinois statute ${ }^{27}$ authorized an employer to insure against loss or damage resulting from injuries to his employees that the statute authorized the employer to appropriate the assets of the policy to the exclusion of his injured victim.

That fallacy permeates many decisions. In a much cited Massachusetts case, ${ }^{28}$ the court, recognizing the harmful social consequences of its decision, declared:

"If the usual result of insurance against liability for damages respecting accidental injuries to others was to give money to the insured when he was not obligated to compensate the person injured, it would be for the Legislature to say whether such insurance should not be prohibited as contrary to public policy." 29

In the face of such a problem, it ill-becomes any learned court to make such an unfounded confession of impotence. Even though the statute permitted the employer to insure against liability or loss from accident to his em-

${ }^{23}$ Smith Stage Co. v. Eckert, 2I Ariz. 28, 36, I84 Pac. I001, I003 (I9I9).

2t Rollins, Proposal to Extend the Compensation Principle to Accidents in the Streets (rgrg) 4 Mass. L. Q. 392, 393. See also Marx, Compulsory Comperusation Insurance (1925) 25 COL. L. REV. $164,184$.

Kinnan v. Globe Indemnity Co., 233 IIl. App. 451, 457 (I924).

${ }^{2}$ Ives, Compulsory Liability Insurance with Special Reference to Automobiles (1925) 59 AM. L. REv. I39, I44.

${ }^{27}$ Supra note 25, at 455 .

${ }^{23}$ Bain v. Atkins, I8I Mass. 240,63 N. E. 4 I4 (1902).

${ }^{29}$ Supra note 28 , at $245,63 \mathrm{~N}$. E. at 4 I5. 
ployees, it requires no superior sensibilities to know that such indemnity was not designed to enable the employer to exploit his employees. To the extent that the assets of the policy or their equivalent were not made available to the injured employees, it was "graveyard insurance". And, certainly, such a policy was not within the purview of the law. It would seem that the court was suffering primarily from a lack of resourcefulness, and not from a lack of power.

Very often, the same fallacy is found beneath another guise. A New York court ${ }^{30}$ formulates the defective argument this way: "The owner of an automobile is not required to procure liability insurance. When he does so, it is for his own protection." No court seems ever to have attempted to define the limit of the insurable interest which the assured has in the life and limb of his prospective victim. He has an insurable interest only to the extent of the amount which his victim receives from him in settlement of damages for his injury. If he receives more than that, he profits by his own wrong. It was the welfare of the victim which prompted Mr. Justice Nunn, dissenting, to say:

"But if the principle of insurable interest be overlooked or disregarded, then the business is indefensible, and becomes a curse to society. ${ }^{31}$. . . And I am sure no method of construction should be adopted which . . . would create an inducement for the employer to be careless of the safety of his employees, without at the same time giving the employee a right under the contract to be compensated for an injury growing out of the increased hazard which the contract caused." 32

Certainly, it is clear that unless the assured actually appropriates the assets of the policy or the equivalent to payment of damages to the injured person, he has no insurable interest in the life or limb of his victim. He is either a gambler or a trickster and a fraud. Whether he was compelled to take out insurance or not, has nothing to do with the question. If he does take out insurance, it is a sine qua non to the validity of the contract that he shall not profit by his own liability for negligence. The fundamental question, from a social point of view, is not whether a policy to indemnify against a liability for killing is valid, ${ }^{33}$ but rather whether any judicial construction of such a policy which does not give primarily the benefits of it to the injured person is defensible. Generally, the validity of the policy is conceded. The controversy has been over the short-sighted judicial inter-

${ }^{20}$ Hermance v. Globe Indemnity Co., 221 App. Div. 394, 398, 223 N. Y. Supp. 93, 97 (I927) ; aff'd without opinion, 2.5 I N. Y. 5I3, 168 N. E. 409 (I929).

"Fidelity \& Casualty Co. of N. Y. v. Martin, I63 Ky. I2, 32, I73 S. W. 307, 315 (1915).

2 Supra note 31, at 35, 173 S. W. at 316.

${ }^{*}$ Motor Insurance and Public Policy (I927) I63 L. T. 269. 
pretation which has shown a serene indifference to predatory practices of a crass and brutal individualism. ${ }^{34}$

In discussing the right of the injured to receive ultimately the benefit of the policy, Lord Hanworth recently said:

"Now I think it is quite clear that most people would think that there ought to be a right on the part of $\mathrm{Mr}$. Chaplin (injured) to recover the sum which has been paid to the defendants (assured) in the action on the strength of the liability under which they had been placed to him... .

". . . It is, perhaps, unfortunate that one should have to give a judgment which would, at first sight, appear to run counter to what I might call the common-sense view of the proceedings. None the less it is necessary for us to administer the law as it stands . . ."35

And so the Master of the Rolls sacrificed his victim at the altar of jurisprudence, when he should have merely accorded him the benefits to which common-sense entitled him. The court sympathized with the victim; Mr. Justice Lawrence ${ }^{36}$ apologetically said:

"Of course, however much we may sympathize with the appellant in this case, we cannot allow that sympathy to lead us astray, or to do otherwise than to administer the law as it exists."

According to Dean Pound's test, the English court failed in its resourcefulness. For the task of a judge is to make legal principles vital by achieving, through useful labor, a just result in the intelligent application of the principles of law to a concrete case. ${ }^{37}$ Compare this "strong decision", due to the sympathetic short-sightedness of the English court and decidedly opposed to common sense, ${ }^{38}$ to the illuminating appreciation of $\mathrm{Mr}$. Justice Doerfler, dissenting, in a Wisconsin case : ${ }^{39}$

"The assured, in taking out a policy of this kind, has in mind the accomplishment of two purposes; first, the creation of a fund out of which a person injured through the involuntary negligence of the assured may be in a degree compensated for such injury; second, a protection to himself from liability under the policy on the happening of an injury. The former consideration is perhaps of greater importance to the assured and the public than the latter. The public is interested to the extent of having due compensation paid to the injured, so that he may not become a burden or charge upon the community. Such a

a Weyc, The New Democracy (I927) 43. (rgag).

In re Harrington Motor Co., Ltd. [I928] I Ch. I05, IIO, III, 59 A. L. R. IIII, III4

${ }^{\text {ss }}$ Supra note 35 , at 124, 59 A. L. R. at II22.

${ }^{s}$ Pound, Mechanical Jurisprudence (I908) 8 CoL. L. REv. 605, 622.

${ }^{33}$ Supra note 37, at 608 . (Ig2I).

${ }^{20}$ Glatz v. General Acc. Fire \& L. Assur. Corp., I75 Wis. 42, 50, I83 N. W. 683, 686 
policy is also designed to inure not only to the benefit of the injured, but in many cases to the benefit of his immediate dependents in case the injury results in death."

Accordingly, one feels the social interest will not tolerate the assured to receive from the policy any greater benefit than he bestows upon the person whom he injures. And the extent of his insurable interest in the life of the injured party is measured by benefits which the injured is to receive under it, because the assured cannot profit by it.

\section{Indemnity: Loss v. Liability}

Indemnity policies have been said to be divided into two well recognized classes: policies to indemnify against loss and policies to indemnify against liability. ${ }^{40}$ Loss from liability arises immediately upon one becoming liable to another, and not from loss which arises upon such liability being paid and extinguished. The distinction has been well expressed in a Missouri case : ${ }^{41}$

"There is a well recognized difference between contracts of indemnity against loss and contracts of indemnity against liability. In the former the insurance company does not become liable until loss has actually been suffered and the amount of insurance does not become available until the assured has paid the loss, whereas in the latter case the obligation of the insurance company becomes fixed when the liability attaches to the insured."

However, frequently the word "indemnity" is used inaccurately by way of contrast to "liability" to distinguish the two types of policies, when in fact the latter is also a policy of indemnity. ${ }^{42}$

Professor Williston approves this distinction which has been made repeatedly in the decisions. He says that it is a distinction sound in principle, though often difficult to draw in fact. ${ }^{43}$ That it is sound may well be doubted. The difficulty in drawing the distinction in fact seems to be per-

${ }^{20}$ Maryland Casualty. Co. v. Peppard, 53 Okia. 515, 522, I57 Pac. I06, I08 (Igr6).

“Klotzbach v. Bull Dog Auto Fire Ins. Ass'n, 267 S. W. 39, 40 (Mo. App. 1924). See also Fidelity \& Casualty Co. v. Fordyce, 64 Ark. 174, I79, 4 I S. W. 420, 422 (I897); Transylvania Casualty Ins. Co. v. Williams, $209 \mathrm{Ky} .626,629,273 \mathrm{~S}$. W. 536 (I925); Capelle v. United States Fid. \& Guar. Co., 80 N. H. $48 \mathrm{I}$, I20 Atl. 556 (I922) Gilbert v. Wiman, I N. Y. 550, 563 (I848); Howard, Insurance-Right of Injured Party to Sue (I929) 9 ORE. L. REV. 57, 63 .

2 Note (1924) 24 CoL. L. Rev. I73, 175. See also American Employers' Liability Ins. Co. v. Fordyce, 62 Ark. 562, 569, 36 S. W. $105 I$, 1053 (I896); McBride v. Aetna Ins. Co., 126 A.rk. 528, 532, I9I S. W. 5, 6 (19I7); Note (rg25) 37 A. L. R. 644.

"Winuston, CoNTrACTS (I920) \& I409. "Generally speaking, a liability does not become a loss till the person liable parts with or is deprived of something of value in consequence of the liability. A judgment fixes the liability, but there is no loss or damage until the person liable, the judgment debtor, parts with something of value in payment or satisfaction of the same." Sturgis, P. J., in Stag Mining Co. v. Missouri Fidelity \& Casualty Co., 209 S. W. 32I, 323 (Mo. App. IgI9). 
suasive reason for doubting its soundness. An analysis of the cases seems to prove that it is formal and artificial.

In an early Minnesota case, ${ }^{44}$ a bond was given "to indemnify . . . against any legal liability." To solve the problem which the litigants raised the court religiously resorted to the dictionaries, the authoritative sources of verbal light. It found that Webster and Worcester agreed that to "indemnify" was "to save harmless" or "to secure against loss or damage". Although the word could be used in two senses, by some mysterious process -perhaps it was mathematical-the court concluded that "indemnity" in the bond was used in the latter sense. Of course, legal science has progressed since 1870 (the date of the case). The legalists of today, probably, would not approve the decision. Still, it is admitted that there is a conflict ${ }^{45}$ as to whether any given language makes a policy one of indemnity against liability or against loss.

Generally, indemnity against loss from liability is not construed to be indemnity against liability. ${ }^{46}$ But Oklahoma ${ }^{47}$ says :

"In our judgment, it is faulty reasoning which leads to the conclusion that one can suffer no loss if he is unable to pay that which he is under obligation to pay. Many modern business men, we dare say, would deem the loss of money insignificant compared to the loss of good name, not to mention other losses which inevitably follow inability to meet honest obligations."

In some cases in order to make it clear that indemnity against loss really meant "loss", it was characterized as an "actual loss" 48 or "actual pecuniary loss". ${ }^{49}$ Even the descriptive additions did not identify clearly the particular loss. The Federal Circuit Court of Appeals seems to have discovered why.

" 'Loss' is not a word of limited, hard and fast meaning. There are many kinds of loss, besides money out of pocket. No man would doubt that he might rightly call a 'loss' that event which changed his status from solvency to insolvency, and compelled him to go through bankruptcy or else be unable to own any property as long as he lived. Indeed, in the strictest sense of the word, the business man against whom a judgment of this kind became final during a fiscal year, so that at the end of that period he must carry it on his books as a liability, would, according to all familiar systems of bookkeeping, enter it as a loss for that period, and treat it accordingly . . "\$50

"Weller v. Eames, I5 Minn. 46r, 467 (1870).

Es Blanton v. Cotton Mills Co., I03 Kan. I18, I24, I72 Pac. 987, 990 (1018).

${ }^{4}$ Carter v. Aetna Life Ins. Co., $76^{\circ}$ Kan. 275, 277, 91 Pac. 178, 179 (I907); Griffin v. Casualty \& Surety Co:, 231 Mich. 642, 645, 204 N. W. 727, 728 (1925); Cayard v. Robertson, I23 Tenn. 382, 385, 13I S. W. 864, 865 (I910).

"Maryland Casualty Co. v. Peppard, supra note 40, at 522, 157 Pac. at 108.

cs Elliott v. Belt Automobile Ass'n, 87 Fla. 545, 546, noo So. 797 (1924).

$\infty$ Griffin v. Casualty \& Surety Co., supra note 46 , at 644,204 N. W. at 728.

wo Schambs v. Fidelity \& Casualty' Co., 259 Fed. 55, 58, (C. C. A. 6th, I9r9). 
To make the problem more difficult for the courts to determine whether the indemnity was against liability or loss, the policies seem to have been drawn to savor of both. ${ }^{51}$ And in one case, ${ }^{52}$ the court was embarrassed by the danger of being guilty of the intellectual obtuseness of not distinguishing between "for loss or damage" and "against loss or damage". But, judicial acumen was equal to the emergency and successfully made the hurdle.

\section{The Prattle About Privity}

Bain v. Atkins ${ }^{53}$ is one of the most nauseating cases to be found in the books. Its vicious influence has been far-reaching. Atkins was a contractor and builder in Boston who was protected by an accident policy. One of his workmen dropped a brick on Bain, a ten-year-old boy, causing serious head injuries. Bain recovered a judgment of $\$ 7000$ against Atkins. Nine days before Bain attempted to liquidate his claim, the accident company settled with Atkins for $\$ 3000$. At the time of the settlement Atkins had been cited in the poor debtors' court on a judgment of $\$ 185$ which had been obtained against him; thereafter he became bankrupt. The question before the Massachusetts court was: What right has the injured person to the assets of the accident policy? The court answered "None". Did not the unsophisticated insurer settle in good faith? ${ }^{54}$

"The only parties to the contract of insurance were Atkins and the company. . . Not only was the plaintiff not a party to either the consideration or the contract, but the terms of the contract do not purport to promise an indemnity for the benefit of any other person than Atkins. The policy only purports to insure Atkins and his legal representatives against legal liability for damages. . . . It contains no agreement that the insurance shall inure to the benefit of the person accidentally injured, and no language from which such an understanding or intention can be implied. Atkins was under no obligation to procure insurance for the benefit of the plaintiff. . . ." 55

Nevertheless, according to the result of the case, both parties to the contract were permitted by the decision to traffic in the injuries of the boy. Atkins received $\$ 3000$ and had paid only the premium on his policy. The insurer saved $\$ 2000$ by the settlement. Pre-Civil War Massachusetts rose in righteous indignation when the slave owner exploited his slaves by appropriating their labor. A generation later, judicial Massachusetts sanctioned a traffic in the injuries of innocent victims and with ignoble complacency enshrouded it in the mantle of privity. This is not law. Relieve it of its tragedy and it is the burlesque of legal pedantry.

${ }^{01}$ Supra note 49 , at 648,204 N. W. at 729.

${ }^{62}$ Verducci v. Casualty Co., 96 Ohio St. 260, 268, 1I7 N. E. 235, 237 (I9I7).

* Supra note 28.

ss Ibid. at 246,63 N. E. at 415 .

$\infty$ Ibid. 244,63 N. E. at 415 . 
The pious prattle of privity has led many a court "into the impenetrable fogs of endless palaver". ${ }^{56}$ When the assets of an accident policy were made available to the injured party, a dissenting judge cried out in pained amazement "then he is the real party in interest". ${ }^{57}$ When the court denied to the injured employee the assets of his employer's policy, a saner dissenting judge with finer vision said "such a construction of the policy outlaws it, and the business becomes a menace to industry and a threat to its employees".58 He saw the problems of the law as a task in social engineering ${ }^{59}$ nor did he approach them with the warped perspective of the opponent of compulsory liability insurance who dared to assert:

"In my opinion the greatest menace to the institution of private property, the most insidious assault on private rights, the most farreaching invasion of personal liberty ever proposed in this country is the effort to socialize insurance". ${ }^{60}$

Since it is common knowledge that all insurance involves the distribution of loss among large numbers and is based on the socialized application of the theory of averages, his superlatives betoken his prejudice rather than his intellect.

However, it appears that the authorities are quite uniform ${ }^{61}$ in holding that there is no privity of contract between the insurer and the employee or injured person under a policy of indemnity against accident taken out by the employer or other insured third person for his own protection. Indeed, it is of no moment that there is no privity, because that is not the decisive fact. Most of the courts have regarded it as the determining factor. Whether the injured person is a party to the contract or not is irrelevant. What the intent of the parties to the contract was is not controlling. It is assumed that a policy of indemnity against accident is valid. It is also assumed that the insurer and the insured did not intend to engage in an illegal transaction. The only construction which could be placed upon the policy that would sustain its validity is that either the assets of the policy or an equivalent would be made available to the injured person. It is not a question of privity; it is a fact conditioning the validity of the contract. It transcends the contract. What the parties intended is of no consequence. The right of the injured party does not depend upon their intent. It depends upon the limitations which the law has placed upon their right to contract with reference to the injuries and life of another in order

\footnotetext{
so McAdoo, When the Court Takes a Recess (I924) 90.

"Elliott v. Belt Auto. Ass'n, supra note 48, at 560, 100 So. at 802 .

${ }^{*}$ Supra notes 31, 32.

${ }^{6}$ Pound, The Seirit of the Common Law (Ig2i) 195.

${ }^{\infty}$ Ives, op. cit. supra note 26 , at I5\%.

${ }^{\circ}$ Stenbom v. Brown-Corliss Engine Co., I37 Wis. 564, 566, Irg N. W. 308 (Ig09).
} 
that insurance may not be a mere speculation based upon the misfortunes of the victims, which are the subject matter of the contract. To say, as did Mr. Justice Gray, ${ }^{62}$ that an insured employer owes no duty or obligation to his employee, except those which grow out of the relation of employer and employee, is absolutely false. He owes the duty not to enrich himself or his insurer by appropriating the blood money of his employee when he is legally liable for his injury. Yet, in the light of this duty, one court which repudiated these decisions which recognized the interest of the injured party, said:

"It seems to us that their construction of the insurance contract is dominated by an undue regard for the injured stranger, rather than by a consideration alone of the intention and the obligations of the contracting parties. Such insurance contracts as these may be onesided and unsatisfactory in their operation, but we know of no principle of law or public policy which forbids their operation exactly as stipulated by the parties, with which . . . a stranger to the contract has absolutely no concern". ${ }^{63}$

The right of the injured party quite clearly does not rest upon the question of his being a third party beneficiary. ${ }^{64}$ Nor can his right be regarded as derivative from the terms of the contract because it is an essential condition of it. ${ }^{65}$ Nor is the benefit indirect or incidental, ${ }^{66}$ because, unless its primary object is a dedication of its assets or their equivalent to reimburse the victim, the policy falls under the condemnation of the law. He is the real party in interest ${ }^{67}$ and the saving of his tort-feasor from damage is, from a social point of view, but an incident of the transaction. When the New York statute ${ }^{68}$ authorized the employer to take out policies of accident insurance covering his employees colectively for their benefit, it merely recognized the only insurable interest which the employer ever had in the lives of his employees, and relieved the employer of the burden of the risk of their injury within his employment.

Chief Judge Cardozo has said that "A fruitful parent of injustice is the tyranny of concepts". ${ }^{9}$ "Privity has frequently been the source of such tyranny. Its function seems often to have been to make the law scientific for the sake of science. ${ }^{70}$ But in recent years an assault has been made

es Embler v. Hartford Steam Boiler Co., 158 N. Y. 43I, 437, 53 N. E. 212, 213 (I899).

* Goodman v. Georgia Life Ins. Co., I89 Ala. 130, 133, 66 So. 649, 650 (I914).

u Howard, op. cit. supro note $4 \mathrm{r}$, at 58.

* WiIITSTON, CONTRACTS, $\$ 364$.

- Williston, Contracts for the Benefit of a Third Party (1902) 15 Harv. L. Rev. 767, 781. See also German Alliance Ins. Co. v. Home Water Co., 226 U. S. 220, 230, 33 Sup. Ct. 32,35 (I9I2).

G Williston, op. cit. supra note 66 , at 778 . at 212.

N. Y. Cons. LAws (Cahill, I923) c. 30, §55. See supra note 62 , at 435,53 N. E.

.$\infty$ Supra note $\mathrm{I3}$, at $6 \mathrm{I}$, also at 45 .

70 Pound, supra note 37 , at 605 . 
upon its ancient citadel. ${ }^{\mathbf{7 1}}$ In the past, courts have dealt blunderingly with the right of the injured party under accident indemnity contracts very much as the New York Court of Appeals dealt with workman's compensation in Ives $v$. South Buffalo Ry. Co. ${ }^{72}$ Privity seems to have obsessed them and induced a mental stupor. The criticism of Ward seems especially appropriate:

"Elaborate judicial opinions, as is well known, not only tend to obscure the subject, but actually befog the judge's mind, divert it from the central notions of justice or right involved, and lead it to decide questions wrongly where the truth is intuitively arrived at by others ..." 73

The intuitive judgment, says Ward, is "popularly called 'common sense'." Its virtue is that frequently it averts such intellectual catastrophes, which are so profoundly depressing.

The notion of privity in its essence is merely the subordinating of a claim as an incident to a relation. The legal relation created by the tortious act of injury never should have been subordinated to the relation of privity which was established as a protection against the tortious act. The question of privity was a subordinate question. The social interest in the life of the victim of the accident transcends the interest which society has in protecting either the insured or the insurer in the assets, which by virtue of the tort become available. Under the preposterous claims of privity, the cost of the policy to the assured is legally more persuasive than the cost of the accident to the injured. In this judicial assessment, property is valued more highly than life. The personal quality of privity triumphs. The application of the doctrine of privity to this problem was thoughtless, mechanical. But, as Dean Pound says, "The effect of all system is apt to be the petrifaction of the subject systematized". ${ }^{74}$ Then, the barricade of dead precedents bars social progress.

\section{The Defective Analogy}

The real cause of the conservatism of the courts has been attributed to the inflexibility of the judicial mind and its blindness to the changing social order, as well as its exaggerated veneration for ancient principles of law. ${ }^{75}$ Under the old regime, competitors did not mind any conceivable

"Cardozo, Growth of the LAw (I924) 77. See also Ames, Lrectures on Legal HisTORY (1913) 164; Holmes, The Arrangement of the Law-Privity (193I) 44 HARv. L. REv. 738,743 .

20I N. Y. 27I, 3I8, 94 N. E. 43I, 449 (I9II). "I know of no principle on which one can be compelled to indemnify another for loss unless it is based upon contractual obligation or fault." Cullen, C. J.

${ }_{73}$ Ward, Psychic Factors of Civiuzation (I892) 173.

" Pound, Liberty of Contract (I908) I8 Y ALE I. J. 454, 462.

To WEYL, op. cit. supra note 34 , at $\mathrm{II2}$. 
waste of human lives. Hugging the illusion of the power of privity, the drab judicial tragedy of allowing the insurer and the insured to profit at the expense of their injured victim, merely made certain the triumph of commercialism. The conception of social justice was the last to develop. Dean Pound says:

“. . . as a result of our legal history, we exaggerate the importance of property and of contract, as an incident thereof . . . And our courts regard the right to contract, not as a phase of liberty-a sort of freedom of mental motion and locomotion-but as a phase of property, to be protected as such. A further result is to exaggerate private right at the expense of public interest". ${ }^{76}$

The merit of the sociological movement has been that it gives the human factor a dominant position and has demoted logic to its position as an instrument. ${ }^{77}$ Twenty years ago, one writer admonished the courts:

"Let the courts wake up, and not regard so highly the 'business interests' of the country, especially where such interests are opposed to the 'safety of the people'. The latter consideration becomes the 'supreme law' of the land which the courts are charged to enforce". ${ }^{78}$

No one would doubt that accident insurance has the same undisputed social value as it had in 1864 in Massachusetts when it first made its appearance as a form of contract insuring the insured against accidents to his own person. ${ }^{79}$ The modern accident indemnity policy seems to have had its origin in England, in I880, through the passage of the Employer's Liability Act. ${ }^{80}$ In the United States, this new species of indemnity insurance received an impetus $^{81}$ as a result of the decision of Phoenix Insurance Co.v. Erie Transportation Co. ${ }^{82}$ The United States Supreme Court held in this case that:

"No rule of law or public policy is violated by allowing a common carrier, like any other person having either the general-property or a peculiar interest in goods, to have them insured against the usual perils, and to recover for any loss from such perils, though occasioned by the negligence of his own servants. By obtaining insurance, he does not diminish his own responsibility to the owner of the goods, but rather increases his means of meeting that responsibility". ${ }^{83}$

Although it is admitted that the great majority of the earlier contracts were contracts of indemnity for loss of property, it has been assumed that the

${ }^{70}$ Pound, supra note 74 , at 460 .

$\pi$ Pound, supra note 37 , at 609 .

${ }^{78}$ Robbins, Validity of Indemnity Insurance Contracts (Igro) 7r CENT. L. J. 37, 38.

7 Employers' Assurance Corp. v. Merrill, I55 Mass. 404, 406, 29 N. E. 529, 530 (1892).

- Rhodes, The Liability of Insurance Contract (IgII) 4 ME. L. REv. 65.

${ }^{8}$ Collier, The Validity of Contracts of Indemnity for Liability to Third Persons Arising Out of Negligence (I9I0) 7I CENT. L. J. 39.

${ }^{2}$ II7 U. S. 312, 6 Sup. Ct. 750 (I886).

${ }^{2}$ Ibid. 324,6 Sup. Ct. at 755 . 
same principles are "equally applicable" to indemnity against losses for injuries. ${ }^{84}$ The defect of the assumption is obvious. Life and property can not be regarded in the same category. One dissenting judge put the argument in an extreme form:

"In my opinion it is illegal because it is contrary to public policy and because humanity cries out against it. You cannot liken this to a contract of re-insurance against a fire loss, because you can not measure the master's duty to take care for the life of his servant by the same rule of conduct that you measure his right to take care of his property; you can not measure life against money value". ${ }^{85}$

One may admit the accident indemnity policy to be valid, but it is very difficult to see how the employer as tort-feasor could appropriate the assets of the policy at the expense of his victim with the sanction of the law. It is the more incredible when one learns from the cases that an employer has an insurable interest in the safety of his employees. ${ }^{86}$ One would never suspect that it could be made an anti-social source of profit by befogging privity. But, in the conflict between bad logic and good sense, logic won. It illustrates, as Laski says, that ideas lag behind the environment of which they are a part. ${ }^{87}$

\section{The "No Action" Clause}

The earlier forms of policies undertook to protect the insured against liability for the injury inflicted. ${ }^{88}$ Then, although the accident companies still designated their policies "liability" policies, they were changed so that the company undertook only to insure against loss from legal liability. Even these contracts were sometimes construed as indemnity against liability. ${ }^{89}$ The next step by the accident companies was to insert the "no action" clause. From the standpoint of the immunity of the insurer, one of the most perfect of these clauses reads :

"No action shall lie against the company to recover for any loss or expense under this policy, unless it shall be brought by the assured for loss or expense actually sustained and paid in money by him after trial of issue" ${ }^{\prime 90}$

Under such a clause, which was very popular with accident companies and which was adopted generally by them, the insurer was not liable to the as(rgog).

ss Breeden v. Frankford Marine, etc. Ins. Co., 220 Mo. 327, 347. II9 S. W. 576, 579

Vallient, C. J., ibid.

${ }^{30}$ Supra note 79 , at 408,29 N. E. at 53 I.

87 LASKi, CoMMUNISM (I927) 62.

$\approx$ Note (1925) 37 A. I. R. 644, 645.

Ibid. 646 .

${ }^{\circ}$ Patterson v. Adan, IIg Minn. 308, 3I4, 138 N. W. 28I, 284 (I9I2). 
sured until the judgment against him was paid.91 And with a few exceptions, the courts so held. One court said:

"It may be a surprise to many owners of automobiles to find that policies such as we now have before us do not afford them the protection that they supposed they had, but however that may be, we cannot change the contract between the parties to meet special circumstances, if the contracting parties hare not protected themselves".92

When it was argued that where the assured was insolvent, the effect of the "no action" clause, making payment of the judgment a condition precedent, was to relieve the insurance.company from liability, the court would reply:

"The remedy for that injustice, and we agree that it is a gross injustice, must come, if at all, though the Legislature or by the forethought of the insured who will see before he accepts the policy that it is in fact a liability policy as distinguished from an indemnity policy. As long as the law permits the indemnity policy against loss only and the assured will accept it, the courts are powerless to change it.". ${ }^{93}$

These are the constructive suggestions of an apparently helpless court. They relate to the duty of the legislature or of the assured. One is amazed that the insurance departments of the various states should have been so derelict of duty as to tolerate such clauses which, by judicial construction, defeated the very object of accident insurance as a social measure. In spite of the fact that practically eyery state has a department of insurance, yet the "no action" clause was inserted in policies for over twenty years ${ }^{94}$ before any legislative action was taken to nullify it. But the courts failed in their opportunity for granting immediate aid in furtherance of justice. For twenty years most courts impaled their victim upon the "no action" clause. When the insurers changed the wording of their policies in an attempt to make them valueless in event of the insured's insolvency, one court chuckled in gleeful admiration "Vigilantibus, non dormientibus, leges subvenient". ${ }^{95}$ It merely gave expression to the average man's weakness for subtlety and ingenuity, his feeling that law is a mysterious technicality, ${ }^{96}$ when it is merely a travesty on justice.

However, at the hands of a few courts, the "no action" clause fared badly. Practically all policies reserved to the insurer the right to defend all actions. ${ }^{97}$ In 1904 , about the time when the problem of the right of the in-

${ }^{11}$ COOLEY, op. cit. supra note 16,5696 . (1924).

${ }^{2}$ London \& Lancashire Indemnity Co. v. Cosgriff, I44 Md. 660, 667, I25 At1. 529, 532

\$Staggs v. Gotham Mining Co., 208 Mo. App. 596, 600, 235 S. W. 5II, 512 (1921). See also Most v. Massachusetts Bonding \& Ins. Co., I96 S. W. I064, I065 (Mo. App. I9I7).

${ }^{2}$ Beacon Lamp Co. v. Travellers Ins. Co., 6r N. J. Eq. 59, 62, 47 Ati. 579, 581 (I900).

${ }^{\infty}$ Poe v. Philadelphia Casualty Co., I18 Md. 347, 355, 84 At1. 476, 479 (I912).

${ }^{\circ}$ Pound, supra note 37 , at 607 .

$n$ Note $(1920) 6$ A. L. R. 376, 383. 
jured to the assets of the policy became vital, the New Hampshire court ${ }^{98}$ passed on the question. To it the sole question involved was: By an agreement to defend all actions under the policy did not the insurer assume all liability? After an analysis of the meaning of the word "defend", 99 the court concluded by a none too convincing argument that it did. In I9I2, the Minnesota court reached the same result, ${ }^{100}$ adding:

“. . . but if, under the pretense of an insurance obligation, the company carried on litigation in the name of one who has neither voice nor interest therein, and which does not affect the company itself, because the assured is unable or unwilling to pay if plaintiff is awarded judgment, it would seem that the company becomes an officious intermeddler. Public policy does not permit a litigant to so surrender control of his lawsuit to one who has no interest in the cause of action." 101

The rule laid down in these two cases has been followed in a few jurisdictions ${ }^{102}$ and has received legislative approval in many states, but the great weight of authority is against it. ${ }^{103}$ But, what is the "great weight of authority"? Often it is but a "great cloud of dust" that the courts kick up by following each other so blindly. ${ }^{104}$

The New Hampshire rule has been much criticized. ${ }^{105}$ The majority rule has been praised for being more logical. ${ }^{106}$ The minority rule has been called more equitable, though it was denounced as bad law. ${ }^{10 t}$ Perhaps the critic would have been nearer the truth if he has said that the result was good but the rationalization was bad. Mr. Justice Burch exposed the weakness of the New Hampshire decision when he said: ${ }^{108}$

${ }^{88}$ Sanders v. Frankfort, etc. Ins. Co., 72 N. H. 485, 57 Atl. 655 (1904).

$\infty$ Ibid. 496,57 At1. at 658 .

${ }^{100}$ Supra note 90.

${ }^{101}$ Ibid. 313. 138 N. W. at 283.

${ }^{102}$ Elliott v. Belt Automobile Ass'n, supra note 48; Maryland Casualty Co. v. Peppard, supra note 40, at 52r, I57 Pac. at I08; Davies v. Maryland Casualty Co., 89 Wash. 57I, I55 Pac. I035 (1916). Also approved by Nunn, J., dissenting in Fidelity \& Casualty Co. v. Martin, supra note $3 \mathrm{I}$, at 36 , I73 S. W. at 316 ; and Doerfler, J., dissenting, in Glatz v. General Acc. F. \& L. Assur. Corp., supra note 39.

${ }^{100}$ VANCE, op. cit. supra note 20 , at 685 .

${ }^{104}$ Robbins, op. cit. supra note 78 , at 37 .

${ }^{100}$ Allen v. Aetna Life Ins. Co., I45 Fed. 88I, 883 (C. C. A. 3d, Ig06) ; Goodman v. Georgia Life Ins. Co., supra note 63 , at 132, 66 So. at 650 ; Campbell v. Maryland Casualty Co., 52 Ind. App. 228, 232, 97 N. E. 1026, 1028 (I912) ; Carter v. Aetna Life Ins. Co., supro note 46, at 279, 9 I Pac. at I79; Fidelity \& Casualty Co. v. Martin, sipra note 3x, at 29, I73 S. W. at 314; Poe v. Philadelphia Casualty Co., supra note 95 , at 358,84 Atl. at 480 ; Connolly v. Bolster, 187 Mass. $266,269,72$ N. E. 981,982 (1905); Most v. Mass. Bonding \& Ins. Co., supra note 93 , at I065; Cayard v. Robertson, supra note 46, at 388, I3I S. W. 865 ; Combs v. Hunt, I40 Va. 627, 64I, I25 S. E. $66 \mathrm{r}, 665$ (I924); Glatz v. Gerieral Acc. F. \& L. Ass. Corp., supra note 39 , at 48,183 N. W. at 685 .

200 (IgI7) 2 MINN. L. REv. 216, 218.

${ }^{20 \pi}$ (I9I5) 2 VA. L. Rev. $475,476$. (I919).

${ }^{208}$ Emerson v. Western Auto. Indemnity Ass'n, I05 Kan. 242, 245, I82 Pac. 647, 648 
"After accident, an automobile owner is not grievously concerned about either legal liability or expenses so long as an insurance company must pay the bills. To protect itself against indifference, improvidence, and even collusion and downright fraud, the insurer is obliged to undertake the defense, and make its own outlays for expenses. Under these circumstances, the insurer is not put to any election to forego these protective measures, or to give up writing indemnity policies."

Although one must admit the validity of this observation, one can not feel that Mr. Justice Burch has approached the problem from a helpful point of view when he says that "An automobile owner may take or leave such a policy." Contrasted with the sympathetic approach of Professor Vance, ${ }^{109}$ one feels convinced of it.

"This state of the law undoubtedly permitted grave abuses; furthermore it offends the common sense of justice to see an insurance company escape liability merely because the assured is unable to satisfy the judgment, when the insurer is usually regarded as the principal debtor within the limits of the policy, and the assured a mere conduit through whom the money passes. It is not surprising that many attempts have been made by a sort of subrogation to substitute the assured's victim to the assured's right against the insurer freed from the condition of prepayment."

The majority rule, which has been praised so highly for its logical quality, at least exposes the courts to attack for their mental sterility. ${ }^{110}$ The mere fact that the injured party was usually left penniless by the courts when a policy, which was an asset of the assured, was declared valueless, is of itself an indictment of their failure to achieve justice.

\section{Satisfying the Condition Precedent}

The "no action" clause was clearly designed to make payment of the judgment after trial a condition precedent ${ }^{111}$ to the duty of the accident company to indemnify the insured. When the assured was insolvent and not able to pay the judgment, the problem which confronted the injured party was: How could he make the assets of the policy available?

I. By garnishment. The "no action" clause made the policy one of indemnity against loss, requiring the judgment to be satisfied by payment. Without doing violence to the language of the policy, it could not be construed as an indemnity against liability which would make the assets of the policy subject to garnishment as a sum due to the assured under the policy. ${ }^{112}$

${ }^{100} O$ p. cit. supra note 20 , at 684 .

${ }^{210}$ Pound, op. cit. supra note 37 at $6 \mathbf{1 4}$.

III Employers' Liability Assur. Co. v. Fredette, 3 D. L. R. 64, 66 (Ig23), (I923) 29 REv. LEG. (N. S.) 93, 95.

iv Melulkhova v. Employers' Liability Assur. Co., 66 D. L. R. 609, 6r7, 63 Can. S. C. R. 5II, 525 (I922); Maryland Casualty Co. v. Peppard, supra note 40, at 52I; Boling v. Ashbridge, IrI Okla. 66, 238 Pac. 42 I (I925). 
The garnishment could not change the contract between the assured and the garnishee. ${ }^{113}$ No money was due to the assured until the condition had been satisfied.114 For the injured person to maintain garnishment proceedings against the insurer, the insured must have had a subsisting right of action at law, ${ }^{115}$ for it is a fundamental doctrine of garnishment that the plaintiff acquires no greater rights against the garnishee than the defendant liimself has. ${ }^{116}$ The garnishee has the same defense against the plaintiff which he could plead if action were brought against him directly by the principal defendant on the claim. ${ }^{117}$.

Since under the theory of garnishment the only issue is whether the garnishee was indebted to the principal defendant, ${ }^{118}$ it is amazing that so many proceedings in garnishment should have been brought against the insurer by the injured party to obtain the assets of a policy which contained a "no action" clause. 119 Defeat was inevitable unless the court was willing to nullify the "no action" clause on the erroneous theory of the New Hampshire and Minnesota cases, that by undertaking the defense of the action the insurer is estopped from denying that the indemnity policy was for indemnity against liability. However, dissent against denying recovery in garnishment is frequent. ${ }^{120}$ One dissenting judge favored recovery in garnishment because, excepting for the purpose of preventing collusion between the assured and the injured party, the "no action" clause was a trick on the part of the insurer, a dishonest scheme to avoid liability when the assured was insolvent. ${ }^{121}$

Doubtless the assets could be reached by garnishment where the waiver of the condition precedent makes the policy one of liability, ${ }^{122}$ or after settlement where the condition is that the indemnity shall not be payable until the loss or damage has been adjusted and settled by the company. ${ }^{123}$ Similarly, recovery is allowed by an injured employee in garnishment proceedings against the insurer, where the policy is one against liability for damages. ${ }^{124}$

${ }^{113}$ Drake, Atrachament (7th ed. I89I) §5I7.

${ }^{214}$ VANCE, op. cit. supra note 20 , at 683 .

176 ShinN, AtTachment and GaRnisharent (I8g6) § 516.

${ }^{126}$ International Harvester Co. v. Hanson, 36 N. D. 78, 83, I6I N. W. 608, 609 (19I7); Baker v. Eglin, II Ore. 333, 334, 8 Pac. 280 (I883). See also Garnishment (I9I6) I2 R. C. L. $§ 29$.

uif Kriedler, Garnishee Execution and Supplementary Proceedings (r920) 4.

${ }^{129}$ Smith v. Houston Nat. Ex. Bank, 202 S. W. I81, I83 (Tex. Civ. App. I918).

11 Allen v. Aetna Ins. Co., supra note I05; Scheuerman v. Mathison, 74 Ore. 40, I44 Pac. 1177 (1914) ; Combs v. Hunt, supra note 105; Luger v. Windell, I16 Wash. 375, I99 Pac. 760 (I92r); Glatz v. General Acc. F. \& I. Assur. Co., supra note 39.

${ }^{120}$ Fidelity \& Casualty Co. v. Martin, supra note 31. at 515 .

${ }^{121}$ Melukhova v. Employers' Liability Assur. Co., supra note II2, at 6II, 63 Can. S. C. R. (1913).

Dunham v. Philadelphia Casualty Co., r79 Mo. App. 558, 565, I62 S. W. 728, 730

${ }^{123}$ Stephens v. Penn. Casualty Co., I35 Mich. I89, I90, 97 N. W. 686, 687 (1903).

21 Fritchie v. Miller's Penn. Extract Co., 197 Pa. 40I, 47 Atl. 35I (1900). 
2. By attachment. The "no action" clause makes the right of the assured contingent upon the satisfaction of the condition of payment of the judgment. Some courts refuse to allow a contingent interest to be sold under an attachment. ${ }^{125}$ It has been held that in order to subject a right of the debtor in proper proceedings to satisfy a claim of the creditor the money must be due or become due, subject to no other condition than the lapse of time. ${ }^{126}$ Abstractly it is said to be unjust that a creditor should seize and destroy an interest of his debtor which is so uncertain that it can not be fairly sold. ${ }^{127}$ Such an argument would seem to have no validity when an injured person attempted to attach and sell the policy of the assured in order to subject the assets to payment of the judgment. The value of the policy would be dependent upon the credit of the insurer. So it would seem absurd to consider that the assured's interest was so contingent as not to be subject to levy by attachment. ${ }^{128}$ Practically the adaptability of the remedy invoked ought to determine whether a contingent interest may be subjected to the claim of the creditor. ${ }^{129}$ In Oregon, by statute, ${ }^{130}$ a casualty or indemnity policy is subject to attachment upon execution issued on the judgment of the person who has suffered the injury or damages.

3. By execution. The mortgagor of land is the possessor of what is called an "equity of redemption". It is often regarded as an interest in land which is dependent upon a condition, the payment of the amount of the mortgage within a certain time. In 1803 , in a Connecticut case, ${ }^{131}$ the question was: Can the "equity of redemption" be seized on execution? The court's answer was that it is the policy of the law that every species of property should be liable for the payment of a man's debts; a Montana statute so declares. ${ }^{132}$ If the indemnity policy may be seized as an asset and sold on execution, if the judgment debtor purchased it, his judgment would be satisfied to the amount of his bid. ${ }^{133}$ The right of action upon the policy against the insurer would then be perfected, because the appropriation of the policy as an asset of the debtor would satisfy the judgment as well as the condition precedent, imposed by the "no action" clause. The English court had the power, in its discretion, to allow execution. ${ }^{134}$ But the very idea

${ }^{200}$ Frederick v. Chicago Metal Co., 221 App. Div. 588, 589, 224 N. Y. Supp. 629 (Ig27), Finch, J., dissenting, rev'g I30 Misc. 366,223 N. Y. Supp. 824 (1927). See N. Y. C. P. A. $\S 9 \mathrm{I} 6$.

${ }_{123}$ Overturf v. Gerlach, 62 Ohio St. 127, 129, 56 N. E. 653 (I900).

127 What contingent interests may be reached by a creditors' bill? Note (Igro) 27 L. R. A. (N. S.) 454 . (I92I).

${ }_{123}$ Stagg v. British Controlled Oilfields, Ltd., II7 Misc. 474, 480, I92 N. Y. Supp. 596

Supra note 127, at 455 .

150 ORE. CoDe ANN. (1930) § 3-109.

131 Punderson v. Brown, I Day 93 (Conn. I803).

12 Raymond v. Blancgrass, 36 Mont. 449, 464, 93 Pac. 648, 653 (Ig08).

12 FREEMAN, JUDGMENTS (5th ed. I925) \& II39.

${ }^{23}$ In re Harrington, Motor Co., supra note 35 , at 120, 59 A. L. R. at I120. 
of allowing execution against the insurer, where the policy was one of indemnity against loss, was so revolting to its moral sense that it refused because "it would be wrong to allow execution to issue". Whoever purchased a policy, if it were subject to being seized upon levy of execution, would unite in himself the rights of both the creditor and the debtor. In that event, there would seem no doubt that the insurer would have to pay the policy. ${ }^{135}$ To refuse to allow the execution was to deny that the policy was an asset of the assured, which is folly.

4. By assignment. An indemnity policy with a "no action" clause is an asset of the assured even prior to payment of the judgment. ${ }^{136}$ By the ancient common law, things in action were not assignable. ${ }^{137}$ This was considered

". . . the great wisdom and policy of the sages and founders of our law, who have provided, that no possibility, right, title, nor thing in action, shall be granted or assigned to strangers . . ." 138

Pomeroy says that the "perfection of human wisdom" of Lord Coke was semi-barbarous even in Lord Coke's day. ${ }^{139}$ By a wisdom less ancient, now all claims and choses in action are assignable, particularly where the only obligation is to pay money. ${ }^{140}$ A policy under which a loss has occurred, but which has not yet been paid by the assured, so as to perfect the right of action under it is more than a mere hope of acquiring future property. ${ }^{141}$ It is an inchoate right.

Under the modern doctrine, one of the incidents of a chose in action is the right to assign it. ${ }^{142}$ Any provision that its assignment, after the insurer becomes liable under it, shall invalidate the policy, is void. The law favors assignments by which the assets of insolvent debtors may be distributed among their creditors. ${ }^{143}$ To prohibit an assignment of the policy of the assured after liability attached would mean its loss to creditors and ought to be held void. In Georgia, the statute declares that after loss, the transfer of the policy shall not affect the liability of the insurer. No right of the insurer can be affected by it and hence it would be a mere act of caprice and

${ }^{235}$ Scott v. Purcell, 7 Blackf. 66, 68 (Ind. I843) ; Campbell v. Lowe, 9 Md. 500, 508 (1856) ; Travellers Ins. Co. v. Moses, 63 N. J. Eq. 260, 262, 49 Atl. 720, 721 (Igor); Wood v. Jackson, 8 Wend. 9, 37 (N. Y. 1831); Clark v. Bonsal, I57 N. C. 270, 273, 72 S. E. 954, 955 (I9II) ; Briley v. Cherry, I3 N. C. 2, 5 (1828).

${ }_{230}$ Garetson-Greason Lumber Co. v. Home I. \& Acc. Co., infra note 178, at 530; Clark v. Bonsal, supra note r35. But see Illinois Tumnel Co. v. General Acc. F. \& L. Ins. Co., 219

III. App. 25I, 253 (I920).

${ }_{15 T}$ PoMreroy, EQ. JURIs. (4th ed. I9I9) § I270.

123 Lampet's Case, io Coke $46,48 a$ (Io Jac. I).

100 Pomeroy, op. cit. supra note 137 .

${ }^{10}$ Costigan, Doctrine of Boston Ice Co. v. Potter (Ig07) 7 CoL. L. Rev. 32, 33; Assignments, 5 C. J. (IgI6) § 31 .

11 PoMERoy, op. cit. supra, note 137 , at § 1286.

${ }^{10}$ Alkan v. New Hampshire Ins. Co., 53 Wis. 136, 144, 10 N. W. 9r, 95 (188r).

${ }^{10}$ Infra note I45. See also supra. note 124. 
bad faith to withhold consent in order to defeat the claim of the assignee. ${ }^{144}$ Any express provision against assignment is null and void, as an illegal restraint on alienation. ${ }^{145}$ On that sharp condition, the company can not impale the assignee. ${ }^{146}$

In Davies $v$. Maryland Casualty Co., ${ }^{147}$ the Washington court said there is a difference between the injured party who has been assigned the indemnity policy by the assured in payment of his judgment and who then sues to recover on the policy, and the injured party who prior to payment of the judgment attempts to collect from the company as garnishee. In the one case, the condition of the "no action" clause has been satisfied; in the other, it has not been satisfied. Five years later, in Luger $v$. Windell, ${ }^{148}$ the same court denied that any such distinction exists. The denial seems dogmatic. The distinction clearly exists, but the court seemed unable to perceive it.

5. By payment with note. In Davies v. Maryland Casualty Co., ${ }^{149}$ the plaintiff's husband, who was a miner, was killed in the course of his employment. The coal company was protected by a policy of indemnity against loss. After prolonged litigation (nearly two years), a judgment of $\$ I 7,000$ was obtained against the coal company. It was then insolvent; it had no assets. The coal company executed notes for $\$ 17,000$ to satisfy the judgment, which was discharged. The notes were surrendered on the same day they were given in consideration of the assignment of the rights of the coal company under the indemnity policy. When the widow, as assignee, sued upon the policy, the court called this transaction a subterfuge..$^{150}$

Repeatedly, it has been held that where a note is given by a debtor in satisfaction of an obligation, it is deemed a payment of it. ${ }^{151}$ Payment need not be made in money or property $;^{\mathbf{1 5 2}}$ it may be made by note. When payment is made by note, there is no error in excluding evidence of the insolvency of the maker, when he sues upon a contract of indemnity: ${ }^{153}$ Has the debtor, who is insolvent, suffered a loss by making payment by note?

Much of the judicial nonsense on this question, which has gained considerable currency, came from a Wisconsin case, which was decided in Igog.

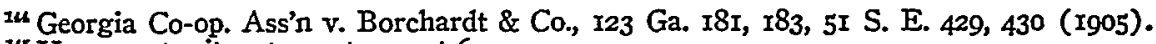
us VANCE, op. cit. supra note 20 , at 642 .

210 West Branch Ins. Co. v. Helfenstein, 40 Pa. 289, 299 (I86I).

178 g Wash. 57r, 578, I54 Pac. III6 (Ig16).

us Supro note II9, at 379, 199 Pac. at 761 .

${ }^{110}$ Supra note 147 .

15o Ibid. 573, 154. Pac. at III7. On rehearing, the court affirmed a recovery by the widow, but shifted the grounds of its decision.

${ }^{152}$ SEDGWICK, DaMAGes (9th ed Igra) \$ 798. See also Gardner v. Cooper, 9 Kan. App. 587, 58 Pac. 228 ( I899); Atkinson v. Stewart, 2 B. Mon. 348, 349 (Ky. 1842); McLeilan v. Crofton, 6 Greenl. 307, 314 (Me. 1830) ; Bausman v. Credit Guar. Co., 47 Minn. 377, 379, 50 N. W. 496 (I8gI); Witherby v. Mann, II Johns 5I8, 520 (N. Y. I8I4).

ios Flannagan v. Forrest, 94 Ga. 685, 21 S. E. 712 (I894).

20 Wilson v. Smith, 23 Iowa 252, 256 (1867). 
In Stenbom v. Brown-Corliss Engine Co., ${ }^{154}$ an employee had recovered a \$10,000 judgment against his employer for personal injuries suffered by him. The Engine Company, which had a "no action" indemnity policy to protect it, was insolvent; later it was adjudicated a bankrupt. After the employee's judgment was obtained, a receiver of the judgment debtor was appointed. He filed a petition in the bankruptcy court, requesting that the indemnity policy be assigned to him by the trustee in bankruptcy. The petition was granted. The receiver gave to the injured employee his note for $\$ 5000$ in satisfaction of the judgment, which was discharged. Action was then begun on the policy. After much prating about privity, the Wisconsin court denounced the action as "a novel proceeding".

"On its face the action taken was a mere subterfuge resorted to for the purpose of making a nominal compliance with the terms of the insurance contract. The contract was one which the parties thereto had a right to make, and it would be trifling with its terms for a court to hold that the shadowy payment here attempted to be made conformed to its requirements. . . . The fictitious payment resorted to is too thinly veiled to stand the test of judicial scrutiny." 1505

If the trustee in bankruptcy had done what the receiver did, the estate would have realized on the policy as an asset. It was the duty of the trustee in bankruptcy to make the assets of the estate available to its creditors. ${ }^{156}$ Such a decision ignores, with perverse blindness, that the policy was an asset ${ }^{157}$ of the bankrupt. If the condition precedent could be met, the money could be made available. The trustee in bankruptcy as assignee of the policy would have the same right to satisfy the condition of the policy by paying the judgment by note as the assured would have had. The puerile fallacy of the Wisconsin case is that the court thought the value of the policy, as an asset of the assured, depended upon the solvency of the assured, when in fact, under a system of credit, it depended upon the solvency of the insurer.

How sadly the Wisconsin court suffered from a "jurisprudence of conception" is illustrated in Eberlein v. Fidelity \& Deposit Co., ${ }^{158}$ in which the court followed the Stenbom case. An injured employee recovered a judgment of $\$$ I 500 from his negligent employer, a corporation which was insured by a "no action" indemnity policy. The employer became bankrupt prior to the liquidation of the employee's claim. It was admitted that the unliqui-

${ }^{154}$ I37 Wis. 564, II9 N. W. 308 (1909).

IIs Ibid. 568 , II9 N. W. at 309. R. at 525 .

${ }^{160}$ Melukhova v. Employers' Liability Assur. Co., supra note II2, at 6I7, 63 Can. S. C.

${ }_{107}$ Emerson v. Western Auto. Indemnity Co., supra note I08, at 246, 182 Pac. 649; Fuller v. N. Y. Fire Ins. Co., I84 Mass. 12, 14, 67 N. E. 879, 880 (I903) ; Newton v. Seeley, I77 N. C. $528,529,99$ S. E. 347 (1919). See also Howard, op. cit. supra note 41 , at 58; supra note 136 .

${ }^{163}{ }^{164}$ Wis. 242, I59 N. W. 553 (I9I6). 
dated claim was not provable in bankruptcy and that the indemnity policy did not pass as an asset of the bankrupt to the trustee in bankruptcy. ${ }^{150}$ In order to satisfy the judgment and meet the condition of the policy the treasurer of the corporation borrowed $\$ \mathrm{I}_{5} \mathrm{Oo}$ from the bank to pay the judgment for which he gave the note of the corporation under a resolution specifically authorizing him to do so. The money so received from the bank was deposited with the bank in the name of the assignee of the employee to be held by the bank as security for the payment of the note of the employer, which the assignee of the employee endorsed. The assignee of the employee discharged his judgment. Was this payment of the judgment? The court held that it was not. To hold otherwise, said the court, is "to make substance out of shadow". ${ }^{160}$ The obtuseness of the court consists of its inability to perceive that a solvent assignee is entitled to loan his credit to make available the assets of the policy held by an insolvent debtor. Mr. Justice Holmes cites with apparent approval the practice of the master who penalized his valet whenever he showed a lack of imagination. ${ }^{161}$ What is to be done with judges who exhibit the same mental defect? This case is the more remarkable because it involved the right of an employee to recover from his employer for injuries due to negligence and because it was written by Chief Justice Winslow five years after his famous decision ${ }^{162}$ sustaining the validity of the Workmen's Compensation Act. That decision Dean Pound said ${ }^{163}$ was the beginning of "something very like sociological interpretation" in this country. The prattle about the absence of privity between the insurer and the injured employee as well as the prattle about the shadow of substance in payment of a judgment by note shows little comprehension of the issues involved in the Eberlein case. In the light of the able opinion in Borgnis v. Falk Co., ${ }^{104}$ sustaining workmen's compensation, the distinguished chief justice was guilty of displaying the product of a mind which was at least momentarily compartmental. When one reviews the judicial decisions of the first quarter of the century on the right of the injured person in an indemnity policy, and then finds a statement by a prominent professor of law that by ro25 the accident companies had recognized the social purpose of indemnity insurance ${ }^{105}$ by inserting a proviso that the company will pay the injured person, even though the insured becomes insolvent or bankrupt and does not suffer a loss, by payment of the damages, one feels that the author of such a statement is ill-informed.

${ }^{160}$ Ibid. 245,159 N. W. at 554.

${ }^{100} \mathrm{Ibid} .246,159 \mathrm{~N}$. W. at 554 .

101 Holmes, Colrected PaPERs (I92I) $20 \mathrm{I}$.

100 Borgnis y. Falk Co., I47 Wis. 327, 133 N. W. 209 (I9II).

100 Pound, Courts and Legislation (I9I3) 7 Arr. Por. Scr. REv. 36r, 380.

${ }^{104}$ Supra note 162.

${ }^{20}$ Chamberlain, Insurance for the Benefil of Third Persons under Statute (I925) II A. B. A. J. 84 . 
The decisions in the Wisconsin cases are not only specious, but indefensible. Fortunately, Wisconsin represents the distinctly minority view. Some cases make a feeble attempt to distinguish the Wisconsin cases. ${ }^{166}$ The effective answer to the insurer's defense of payment by note as a subterfuge is that:

"While it might be contended, by way of argument, that the method of arranging this whole matter was only consistent with some prearranged plan to avoid the terms of the policy, yet, the pith of the question is in the validity of the note as a claim legally collectible . . " 167

from the assured. Discounting a note at a bank by the assured to pay a judgment which will make the assets of the indemnity policy available is merely a commercial transaction in the ordinary course of business.

When the assured is insolvent and he has paid the judgment against him by note, the gist of the insurer's defense on a "no action" policy is usually a lack of good faith. 'When the assured is solvent and he has paid the judgment by note, the gist of the insurer's defense on a "no action" policy is generally that there has been no loss to the assured. Even though the note was not secured, yet if the assured had sufficient property out of which to pay it, it must have been given in good faith. ${ }^{168}$ In order to realize on a "no action" policy, the assured is not obliged to wait until his property is seized on levy of execution on the judgment and his business destroyed. Satisfaction of the judgment by a note is sufficient. When the assured gave its note to the injured employee in satisfaction of his judgment and agreed to use the assets of the indennity policy to pay the note, it agreed to do only what it was its duty to do. ${ }^{169}$ There is no impropriety in giving the injured party the benefit of the insurance. When a judgment has been obtained by the injured party and the only question is as to the method of its satisfaction, it is difficult to see how the question of good faith in discharging the judgment by note is material, where the judgment is actually discharged.

"It is no answer to say that the note may never be paid at all, or that it may be compromised and settled for less than its full amount after the assured is reimbursed by the surety company. This can happen no matter how the note is paid. Had the assured paid the judgment in cash out of its own funds, or paid it in money borrowed from another, there could be a secret agreement to repay it, or some part of it, to the assured after the collection is made from the insurance company. But this is beside the question." ${ }^{170}$ (19I2).

${ }^{100}$ Herbo-Phosa Co. v. Philadelphia Casualty Co., 34 R. I. 567, 579, 84 Atl. 1093, 1098

${ }_{100}$ Ibid. 579, 84 At1. at 1098 . (1913).

${ }_{1 e 3}$ Taxicab Motor Co. v. Pacific Coast Casualty Co., 73 Wash. 63I, 635, I32 Pac. 393, 395

${ }_{2 \oplus \infty}$ Standard Printing Co. v. Fidelity \& Deposit Co., I38 Minn. 304, 307, I64 N. W. I022, I023 (1917).

${ }^{370}$ Supra note 168. 
The impeachment of the assured's good faith appears in juvenile form in the argument of the insurer's counsel in Hoagland Wagon Co. v. London Guarantee $\&$ Accident Co., ${ }^{171}$ a Missouri case. An employee of the Wagon Company had recovered judgment of $\$ 5660$ against his employer, which was protected by a policy indemnifying against loss. The Wagon Company had made an assignment of its assets for the benefit of creditors. Besides the judgment, it owed $\$ 4500$ and had only $\$ 3000$ in assets. Thereafter, it borrowed $\$ 5660$ from a third person on its note and paid the judgment of the injured employee. In an action on the policy, the insurer contended that to borrow money to pay the judgment was "a fraudulent creation or acceleration of the loss" by the assured ${ }_{j}^{172}$ that good faith required the assured should not expose the insurer to jeopardy or wilful loss by wilfully borrowing the money to pay the judgment. To this pathetic argument, the court replied:

"It is with very poor grace that the defendant (insurer) urges that the plaintiff (assured) should not have paid this judgment. A court of last resort had adjudged the judgment to be a just one and that it should be paid. Instead of permitting the plaintiff to pay the judgment, the defendant used all the means at its command to prevent its payment, evidently knowing that it would be the final loser."

In an Iowa case, ${ }^{173}$ an insured employer borrowed $\$ 4247$ at a bank and pledged to two stockholders $\$ 8000$ in book accounts who pledged their stock to the bank to secure the payment of the note which was given for the loan, in order to get the money to pay its injured employee's judgment. The insurer contended that the employer would suffer no loss until the loan, which the note represented, was paid. The court held that since the judgment had been paid, it was no concern of the insurer whether the note was paid, even though the stockholders who gave the security might be the losers. ${ }^{174}$ If a stockholder loans $\$ 2000$ to a corporation to pay the judgment of an injured employee, even after an assignment has been made for benefit of creditors, it is immaterial to the insurance carrier how and where the corporation obtained the money or on whose credit it was obtained, when the judgment has been satisfied.175 If some one were to give the money to the assured, even if the assured were hopelessly bankrupt, the court would not inquire into the motive of the generosity of the assured's benefactor. ${ }^{176}$ When the assured has in fact paid the judgment, the insurer can not challenge his good

${ }^{17 \pi} 201$ Mo. App. 490, 212 S. W. 393 (1919).

172 Ibid. 498,212 S. W. at 397. (I9I2).

${ }^{273}$ West Riverside Coal Co. v. Maryland Casualty Co., I55 Iowa I6r, I35 N. W. 414

${ }^{17}$ Ibid. $164,135 \mathrm{~N}$. W. at 415.

${ }_{1 \pi}$ Frank \& Co. v. New Amsterdam Casualty Co., I75 Cal. 293, 298, I65 Pac. 927, 930 (IgI7). But see Campbell v.. Maryland Casualty Co., supra note 105. (19r8).

${ }_{176}$ North Am. Accident Ins. Co. v. Newton, 57 Can, S. C. 577, 6 A. L. R. 1236, 1237 
faith, by proof that the assured borrowed money to pay it. ${ }^{17 t}$ The assured may borrow the money from whomsoever it chooses, even the surety who executed a bond on appeal from the judgment against the assured. ${ }^{178}$ In order to obtain the loan, it may give as security for its note the indemnity policy. ${ }^{179}$ Even though the assured uses his daughter-in-law's money to pay the judgment, he has suffered a loss by the payment. ${ }^{180}$ Where the administrator of the assured pays the judgment, the court will not inquire whether the administrator had the power to execute a note to obtain the money with which he paid the judgment to determine whether the estate of the assured suffered loss. ${ }^{181}$

The stupid perfection of classical refinement was reached by an Illinois court, $^{182}$ as late as 1920 . The. Tunnel Company, an employer, was protected by a "no action" policy. Two of its employees suffered injury by accidents covered by the policy. On execution against the Tunnel Company, the return of mulla bona was made. Thereafter, the Tunnel Company went into the hands of a receiver, in the foreclosure of a mortgage to secure $\$ 30$,$\infty 00,000$ worth of bonds. At the foreclosure sale, the property was purchased for $\$ 5,000,000$, although the obligations of the Tunnel Company exceeded $\$ 40,000,000$. The Utilities Company, which was organized to hold the assets of the Tunnel Company, which were purchased at the sale, because it feared the judgments of the employees might jeopardize their franchise gave $\$ 10,000$ to the Tunnel Company, which was paid to the two injured employees, together with an assignment of the indemnity policy, in full satisfaction of the judgments. The court refused to allow a recovery on the policy in an action brought in the name of the Tunnel Company. The court said :

"At the time the judgments were satisfied it was impossible for the Illinois Tunnel Company to sustain a loss for it had nothing to lose. It was entirely out of business and hopelessly insolvent. While it has been said that the insurance company cannot question where the money comes from, it has further been said that the payment must be in good faith and there must be in fact a loss and not merely a pretended loss as a result of some collusion between the assured and another," ${ }^{183}$

The denial of a recovery seems to have been placed on the basis that the judgments were satisfied solely because the Utilities Company desired to

mm Campbell v. London \& Lancashire Indemnity Co., I68 N. Y. Supp. 300, 30I (19I7). (I9I7).

${ }_{173}$ Garetson-Greason Iumber Co. v. Home Life \& Acc. Co., 13I Ark. 525, I99 S. W. 547

Iro Ibid. 529, I99 S. W. at 548; Hoagland Wagon Co. v. London Guaranty \& Acc. Co., supra note I7I, at 500; 212 S. W. at 397 ; Schambs V. Fidelity \& Casualty Co., supra note 50, at 59 .

iso Lewinthan v. Travelers' Ins. Co., 6r Misc. 62I, II3 N. Y. Supp. I03I, 1032 (Ig09).

${ }^{181}$ Am. Indemnity Co. v. Fellbaum, 225 S. W. 873 (Tex. Civ. App. 1920).

${ }^{202}$ III. Tunnel Co. v. General Acc. F. \& L. Ins. Co., supra note I36.

${ }^{153}$ Ibid. 266. 
remove a cloud from its franchise. The Supreme Court of Illinois denied a petition for certiorari in this case, ${ }^{184}$ yet it is to be said to the credit of the lower court that there was one dissenting judge, who apparently did not agree that to allow a recovery "would be a travesty on justice" nor with the seven pages of prattle of privity with which the court bewildered itself and burdened the books.

What is the source of confusion of the majority view? Quite clearly, it is the conviction that there is a valid distinction between liability and loss. Nothing is more obvious than that the traditional distinction is as formal as it is artificial. In this modern commercial age, when credit is the very essence of commercial enterprise, to assert that a liability is not a loss is to exemplify the subtlety of a sophist. To prevent the assured from paying a judgment by borrowing money and giving a note would smack of the restraint of primitive law. It would nullify the value of a "no action" policy as an asset of the assured. It would nullify a well-established principle, now followed in a majority of jurisdictions, that a debtor may satisfy a judgment against him by his note. A judgment is a secured liability; a note is an unsecured liability. If one satisfies a judgment by paying it with a note, although the judgment is merely a liability, and not a loss until it is paid, payment by note converts it into a loss. How potent is the magic of a note to convert a liability into a loss! Legally, a liability is not a loss. Exchange for the liability on a judgment a liability on a note, and the second liability in the sequence becomes a loss. The courts failed to recognize how specious was the distinction between a loss and a liability, the absurdity of which any system of credit was bound to expose. That failure was the cause of many victories by the accident companies. That deceptive distinction shackled the mentality of the courts which gave it currency. ${ }^{185}$ To maintain that a note given to pay a judgment is not a loss would mean that the assured could never transact business on credit under a policy of indemnity against loss. To befog the issue with accusations of a lack of good faith, as did the Wisconsin court, reveals the mental obscurity of the court. To maintain that there is any substantive difference between the loss due to a liability incurred by a note and the liability incurred by a judgment is the artifice of an analytical mind. It is too formal to command serious consideration despite its ancient traditions. Just how the exchange of a judgment for a note can taint the transaction with bad faith is not clear, ${ }^{186}$ when the only result seems to be to require the insurance company to pay in accordance with the formal terms of its policy and to make available immediately the assets of the policy of indemnity against loss. When one learns that "not

28s Supra note 25 , at 457 .

100 GLENN FraNk, TOMORROW's BusINESS (I930).

${ }^{180}$ Standard Printing Co. v. Fidelity \& Deposit Co., supra note 169 , at 306,164 N. W. at I023; Riner v. Southwestern Surety Co., 85 Ore. 293, 302, I65 Pac. 684, 687. 
only the weight of precedent but also the weight of reason gives support to the doctrine that the making and delivery of a note may be a loss actually sustained", ${ }^{187}$ the "no action" policy becomes as a basis of credit, an asset of the assured, made immediately available by a formal device. By "the weight of precedent and the weight of reason" all judgments may be discharged by notes and all liabilities under a policy of indemnity against loss may be conyerted into losses. The lack of stability of the distinction between a loss and a liability is seen in such a statement as this:

"The execution of a note in exchange for satisfaction (of the judgment) is in legal effect equivalent to the exchange of property therefor. It confers a right to invoke legal process to seize and levy upon property in value equal to the amount of the note . . ." 188

Of course, so would any liability, when matured, create the same right.

A Florida decision illustrates the weakness of the distinction between a loss and a liability, when it says:

"We cannot see how the plaintiff below (assured) could have alleged, that he had sustained any loss, if the policy is good for anything, unless the unpaid judgment against him constitutes a loss. What other loss could he have sustained? If the answer be, 'that he must have paid the judgment' that would not be a loss, if the policy is with a responsible company. Paying the judgment would be not a loss, but a mere outlay of money that would promptly be repaid to him by the insurance company. At least, the insurance company says it will do so.

"Money paid to satisfy a judgment, is not a loss, if a responsible person is obliged to reimburse the one against whom the judgment is held and who pays it." 189

This argument appears, at first sight, to be specious, but it is not. If the "no action" policy is an asset in the hands of the assured, he can borrow money on it. If the insurer is responsible, there is no reason why the policy as a security should not be equal to the liability of insurer on it up to its face value. In the cases, ${ }^{190}$ the insurer repeatedly admits that when the assured is solvent and can readily satisfy the judgment, the company pays the judgment without the formality of having the assured pay it. If the policy is worth the amount of the judgment up to its face value in negotiating a loan to pay the judgment against the insured, then the transaction, which has given the courts so much difficulty, is open to the classic criticism of the Washington court.

${ }^{298}$ Note (I916) 83 CENT. L. J. 357, 358.

${ }^{283}$ Seattle \& S. F. Ry. \& Nav. Co. v. Maryland Casualty Co., 50 Wash. 44, 47, 96 Pac. 509, 510 (1908).

${ }^{189}$ Supra note 48 , at 547,100 So. at 797.

${ }^{100}$ Patterson v. Adam, supra note 90, at 313,138 N. W. at 284; Glatz v. General Acc. F. \& L. Assur. Co., supra note 39 , at 45,183 N. W. at 684 . 
"The judgment has established that claim. Nothing remains except a form. The casualty company in effect says . . . that, if the coal company (employer) will pay her at one end of the desk, the casualty company will pay the coal company at the other end. Not one thing besides, does it argue, is wanting to its liability except this formula. On that process it insists, not because when the coal company shall have first paid and the casualty company shall then have given reimbursement there will result to it a right, claim or even a salvage interest against the coal company or its assets, but because it wishes the thing done in just that way. It will pay a moment after, not a moment before, the coal company pays. If the latter will get a loan for a few moments from some one else and pay the judgment, then the casualty company will hand it a check, perhaps long previously prepared.

"Such mummeries are ill-favored by the law. Technicality, indeed, is not only respectable, but is enforced by courts when even a remote right is exposed to danger. When technicality is invoked, however, to avoid an obligation morally established, the common law usually finds in its arsenal some weapon with which to confront it and to make that a legal which is already a moral debt." 191

No finer indictment of judicial obtuseness is to be found in the books. Even the Washington court itself caught but momentarily a glimpse of light. It still had faith in legal formalism of primitive quality. With little tribute to its creative genius, in a later case, ${ }^{192}$ it unanimously repudiated this decision, because it was unable to perceive any difference between the right of an injured party to the assets of a "no action" policy when he proceeds by way of garnishment and when he proceeds on the policy as assignee of it after his judgment has been discharged.

No genius is required to perceive that if the assured can give his note for a loan, with the policy as security, in order to satisfy the condition imposed by the "no action" clause, he can give his note to the injured party, with the policy as security, to secure the discharge of the judgment to satisfy the condition. If this conclusion is correct, since the policy is an asset, the assured can assign it directly to the injured in satisfaction of the judgment, ${ }^{193}$ thereby satisfying the condition precedent imposed by the "no action" policy. To deny that he can do so, is to deny either that the "no action" policy is an asset of the assured or that all the assets of the assured should be appropriated to the discharge of the assured's debts.

6. By payment, not in cash. Following the suggestion of some illconsidered dicta of a New Jersey case, ${ }^{194}$ decided in Igor, the accident

${ }^{191}$ Davies v. Maryland Casualty Co., supra note I47, at 574, I54 Pac. at III8.

${ }_{182}$ Luger v. Windell, supra note II9, at 379, I99 Pac. at 76r. See also (I92I) 6 MINN. L. REv. 77 .

${ }_{103}$ Rodgers v. Pacific Coast Casualty Co., 33 Cal. App. 70, 74, I64 Pac. III5, II I6 (I9I7). Contra: Hebojoff v. Globe Indemnity Co., 35 Cal. App. 390, I69 Pac. 1048 (I917).

$1 \$$ Travelers Ins. Co. v. Moses, supra note 135. See also Riner v. Southwestern Surety Ins. Co., stipra note I86, at $301,166 \mathrm{Pac}$. at 687. 
companies incorporated in their "no action" clause the requirement that the assured must pay the judgment "in cash" or "in money" as a condition precedent to reimbursement under the indemnity policy. Even a recent writer seems to have succumbed to the potency of this indefensible fallacy. ${ }^{195}$ He characterizes it as one "of particular importance." Few courts have been so unimaginative as to be impressed by its importance. However, one finds àn acute, literal-minded California court warmly supporting the condition as one of the substance.

"Should we construe the term not to be one of the substance of the contract and permit the loss to be recovered regardless of the kind of property which the assured parted with, then it might happen that the latter had paid in land, jewelry, or other merchandise, and thus an issue would arise as to the actual value of the thing given in payment of the obligation against which indemnity was claimed. We have no doubt at all that an insurer can by the condition of its contract relieve itself from difficulties which might attend such a defense in an action upon its policy." 196

It may be that one may contract with another to pay an obligation due to him only in cash or a given kind of money. But, such an argument when applied to an accident policy neglects to consider the interests of the injured party, who is entitled to have the assets of the policy appropriated to the payment of his judgment, according to law. His legal rights to its appropriation can not be limited by any contract between third parties. It is a matter of no moment to the insurer whether the payment was made in money, property or other obligations. ${ }^{197}$ Payment by note shall be deemed the equivalent of payment in cash. ${ }^{198}$ It is as if the money had actually been advanced. ${ }^{190}$ Indeed, on this question, only the Missouri court seems to have been guilty of lending the weight of its influence to exalt form over substance in law. ${ }^{200}$ However, even the Missouri court lent dignity to the exaltation only by a divided court.

So painful have been the arguments in behalf of the distinction, that counsel have urged that payment by check for a note is not payment unless the judgment is paid in money. ${ }^{201}$ However, the argument failed of success. Payment by warrant is treated as payment in cash, ${ }^{202}$ just as is pay-

${ }^{200}$ Supra note 42 ; note (1924) 24 CoLn L. REV. I73, I75.

${ }^{100}$ Hebojoff v. Globe Indemnity Co., supra note 193, at 393, 169 Pac. at 1049.

$19 \pi$ Ralston v. Wood, I5 I11. I59, I72 (I853).

${ }^{108}$ Lee v. Clark, I Hill 56, 58 (N. Y. I84r).

${ }^{200}$ Cox v. Reed, 27 IIl. 434, 437 (I862); Pearson vi Parker, 3 N. H. 366, 369 (I826). See also SeDGwick, Damages, $\$ 796$.

${ }^{200}$ State $e x$ rel. Western Auto. Ins. Co. v. Trimble, 297 Mo. 659, 670, 249 S. W. 902,905 (1923).

${ }^{201}$ St. Louis Screw Co. v. Mastin, 253 S. W. 96 (Mo. App. I923). See also, Lyon v. Northrup, 17 Iowa 314 (1864).

${ }^{202}$ Pasewalk v. Bollman, 29 Neb. 519, 529, 45 N. W. 780, 783 (I890). 
ment in county bonds. ${ }^{203}$ Any bona fide payment of a claim in any property is payment in money. ${ }^{204}$ If it were not, when the injured person executed upon the property of the assured and it was sold to pay the judgment, the assured might not recover on a policy which required the judgment to be paid in cash; if the injured party bought the property, the judgment would never be paid in cash. No court which has passed upon the question of a loss, as a result of execution upon a judgment, has ever given currency to the folly of the Missouri court and denied that it was a loss in money. ${ }^{205}$

7. $B y$ the aid of equity. The function of equity is to provide a remedy where the common law procedure is not sufficiently elastic, ${ }^{200}$ on the theory that justice should be done when the common law does not furnish an adequate remedy. ${ }^{207}$ There are numerous cases where equity has reached a debtor's choses in action when a judgment can not be otherwise satisfied by execution. ${ }^{208}$ The New Hampshire doctrine has been explained on the theory that where the insurer defends an action for the assured and judgment results, in equity, ${ }^{209}$ the insurer becomes the principal debtor to the injured employee. Not only was it equitable that the assets of the "no action" policy, or their equivalent should be applied in satisfaction of the damages suffered by the injured person, but to the extent that courts tacitly permitted or openly encouraged a diversion of, those assets, or their equivalent, they stimulated diabolical speculation in the lives of innocent victims. When under the obsession of privity, courts of equity declared that the injured employee had no legal or equitable interest in the indemnity policy of his employer, ${ }^{210}$ those courts demonstrated their intellectual unfitness to deal with the problem. The majority of courts denounced the New Hampshire doctrine because it did "not seem to rest on any definite principle"..211 For the most part, that meant that the injured party was a stranger to the contract. When it was urged upon the Alabama court ${ }^{212}$ that the interest

203 Wilkinson v. Stewart, 30 I11. 48,58 (1862).

204 Supra note I78, at: 530 , I99 S. W. at 548 .

20 MeBride v. Aetna Ins. Co., supra note 42, at 534, I9r S. W. at 7; Upton Cold Storage Co. v. Pacific Coast Casualty Co., I62 App. Div. 842, 846, I47 N. Y. Supp. 765,768 (1914); Stag Mining Co. v. Fidelity \& Casualty Co., supra note 43 , at 324 ; McKenna v. International Indemnity Co., 125 Wash. 28, 29, 215 Pac. 66 (I923); Komula v. General Acc. F. \& I. A. Corp., Ltd., I65 Wis. 520, 524 , 162 N. W. 919 (1917).

200 WrIIISTON, op. cit. supra note 66 , at 773 .

$2 n$ Boyd, The Economic and Legal Basis of Compulsory Industrial Insurance of Workmen (IgI2) Io MICH. L. REv. 345, 349.

208 Postreroy, EQ. Juris. § 2300.

${ }^{200}$ CoOlex, op. cit. supra note 16,5704 ; Sanders v. Insurance Co., supra note 98 , at 500 , 57 Atl. at 660 .

${ }_{210}$ Kinnan v. Fidelity \& Casualty Co., supra note 22, at 410 ; Fidelity \& Casualty Co. v. Martin, supra note $3 \mathrm{I}$, at $20,173 \mathrm{~S}$. W. at 310 ; Bain v. Atkins, supra note 28 , at $244,63 \mathrm{~N}$. E. 4I6; Burke v. London Guar. \& Acc. Co., 47 Misc. I7I, 93 N. Y. Supp. 652, 653 (I905); Ford v. Aetna Life Ins. Co., 70 Wash. 29, 36, 126 Pac. 69, 71 (1912).

211 Burke v. London Guar. \& Acc. Co., supra note 210.

supra note 63 , at 132,66 So. at 649 . 
of the injured person was a dominant consideration, the dogmatic court exclaimed, "This theory can find no support in any principle of law or equity, and is too untenable for serious discussion". Yet, Vice Chancellor Pitney of New Jersey perceived the interests of the injured employee with clearer vision.

"The real and only meritorious condition precedent of the liability to payment is the suffering of injury by the employee and the recovery of judgment therefor . . . in which the insurance company shall have the opportunity to conduct the defence . . . The actual payment of the money by the defendant in the judgment to the injured employee has in it nothing meritorious, and does not touch the real consideration of the contract." 213

Contrary to the majority of the courts of equity, it seems plainly equitable that the policy should be regarded as an asset which should be dedicated to the payment of damages suffered by the injured person. In New Hampshire, in order order to realize substantial justice equity disregards the formality of procedure, ignoring all discussion of legal justice as serving no useful purpose. ${ }^{214}$

The desire of the Massachusetts court of equity to do justice is seen in Connolly $v$. Bolster. ${ }^{215}$ It was a suppressed desire. The injured plaintiff prayed that a receiver be appointed in order that he might borrow money to satisfy the condition precedent of the "no action" clause. But the conscien-" tious court was powerless because the statute did not authorize a court of equity "to complete inchoate rights so as to create property which would then be the subject of trustee process in an action at law".

The passive attitude of most courts of equity is exemplified by a Pennsylvania decision. ${ }^{216}$ The injured employee prayed that he be subrogated to the rights of his bankrupt employer under a "no action" policy which it held. With marvelous brevity, the court solved its difficulty, without reflection, by ignoring it. Since the employer had paid nothing, by the express terms of the contract, it was entitled to nothing. This was a court of equity in name only; in fact it was merely a court of very limited comprehension. If as a condition of the subrogation of the employee, the court had required. the employee to discharge his judgment as a consideration for the policy as an asset, the condition of the policy would have been satisfied. Where an injured plaintiff can not attach or reach a policy on levy of execution, why should not a court of equity aid him in making the policy available as an asset? If an execution-proof employer refused to assign his indemnity policy, the only asset he had, in satisfaction of the judgment against him,

${ }^{223}$ Beacon Lamp Co. v. Travelers Ins. Co., supra note 94, at 68, 84 Atl. at 583 .

as Lombard v. Maguire-Penniman Co., 78 N. H. Iro, III, 97 Atl. 892 (I9I6).

216 Connolly v. Bolster, supra note 105, at 271,72 N. E. at 983.

${ }^{20}$ Pfeiler v. Penn Allen Portland Cement Co., 240 Pa. 468, 470, 87 Atl. 623, 624 (1913). 
would a court of equity compel him to do so? Would a court of equity compel the insured employer to execute his note to discharge the judgment and to assign the policy as a security for the note? If it would not, then equity relies on form and not on substance. If it would not, then an employer can make the policy available, as an asset, to his debtor by voluntary execution of a note to satisfy the judgment, but a court of equity is impotent to deal with an unwilling debtor, who seeks to defeat his injured creditor, maimed by his negligence. In dealing with these cases, courts of equity have not been courts of justice. Fortunately, a more recent Pennsylvania decision ${ }^{216 a}$. seems to make further appeal to a court of equity unnecessary. Regarding the "no action" clause merely as a sort of "joker", Pennsylvania has endorsed the Minnesota view.

The Kentucky court superficially justifies ${ }^{217}$ the insurer in inserting a clause requiring payment of the loss by the assured as a condition precedent to an action against it so "as to prevent itself from being subrogated to a loss which an insolvent assured was relieved by his insolvency, from paying." Such an observation is not even intelligible, when the insolvent can borrow on his note and give the policy as security for its payment in order to meet the condition of the policy.

In I9ro, an Ohio court repudiated ${ }^{218}$ the idea that there was anything to which an injured person could be subrogated when the assured was protected by a policy of indemnity against loss. By some strange irony, subsequently, the Ohio legislature declared that the injured employee should be "subrogated" 219 to the rights of the insured employer under the policy and so the Ohio court "subrogated" him, because it would be "monumental folly" not to "subrogate" him when the statute said that he was to be "subrogated".220 Perhaps, the use of the word "subrogate" is not wholly fortunate, ${ }^{221}$ but whatever word one uses it requires no peculiar power of penetration to know that, even if the injured acquires no greater rights than the assured, when he is "subrogated" to the rights of the assured, he unites in himself the interest of debtor and creditor. He is in exactly the same position as he would be if the policy had been assigned to him. Even to insist that he must satisfy the judgment before he can recover on the policy would be to say, that as assignee he must pay himself in order to recover.

These cases would seem to show that at the most courts of equity have been absorbed with the mummery of form when they assert that a court of equity can no more disregard the express provisions of a contract than

rae West v. McMillan, 30r Pa. 344, I52 Atl. I04 (1930). For comment, see (193I) 79

U. of PA. L. REv. 982.

${ }_{2 \pi}$ Supra note $3 \mathrm{I}$, at 29 , I73 S. W. at $3 \mathrm{I} 4$.

218 Garrett v. Travelers Ins. Co., I7 Ohio C. C. (N. s.) I97 (I9I3).

${ }^{210}$ OHIo GEN. CODE (Throckmorton, 1926) § 95IO-I.

20 Verducci v. Casualty Co., supra note 52 , at 264 , II $N$. E. at 236 ; see also Ill. Indemnity Exchange v. Indiana Com., 289 IIl. 233, 236, 124 N. E. 665, 667 (Igrg).

201 WIIIISTON, CONTRACTS, \& 384 . 
a court of law.; The only difference between loss and liability is the formal difference of converting one into the other by means of a note, or more directly by an assignment of the policy. For when an assured assigns his policy to his injured creditor to satisfy his judgment, he suffers a loss because he loses his policy, an asset that he, as an honest judgment debtor, was bound to use to pay the judgment against him. To allow the policy to be used to satisfy the judgment is not, by whim of the court, to defeat the purpose of the contract, ${ }^{222}$ but it is to refuse to allow the condition precedent to obstruct reaching a valuable asset of the debtor by an emphasis of form. Clearly, from the commercial, as well as the social, point of view it is not an essential condition as frequently declared, ${ }^{223}$ however much mere legalism may exalt it, as the courts have exalted it in the past. ${ }^{224}$ Viewed in this light, although the New Hampshire doctrine, as a rationalization, was maladroit and may be condemned as "a strained construction of a contract" by the interpreter who suffers from the obsession that the law of contracts shall dominate the law and be kept inviolate, it is eminently sound in its fine disregard of procedure at the expense of a just result. It repudiates the procedural niceties of the mechanical judicial process. ${ }^{225}$ Its social attitude enabled the New Hampshire court to make the law equal to the emergency of justice.

\section{The Rights of General Creditors to Share Blood Money}

Where the estate of the assured is insolvent, if the proceeds of the accident policy are made available in the liquidation of the bankrupt's estate, should the assets be distributed equally among the assured's creditors? The answer to the question would seem very simple, but in the few cases found on the point, the court has never given the seemingly simple answer. Instead of granting relief to the maimed victim of the assured's negligence it has expressed its deep sympathy, because it saw no alternative. If the assured could not profit by an indemnity contract, the subject of which was the negligent injury of his victim, how could his general creditors have any greater right than the assured would have in appropriating the assets of the policy? The courts assume that the bankrupt's assets should be distributed equally among his creditors. ${ }^{226}$ Where an employee loses his right hand through his employer's negligence, probably he must share the proceeds of his insolvent employer's indemnity policy with the other creditors. ${ }^{22}$ The fallacy of any such monstrous result underlies the attempt

20 Scheuerman v. Mathison, supra note II9, at 49, I44 Pac. at II79. But see Cushman v. Carbondale Fuel Co., I22 Iowa 656, 657, 98 N. W. 509 (I904).

22 Supra note 63, at 131, 66 So. at 649 .

204 Ford v. Aetna Life Ins. Co., supra note 210, at 34, 126 Pac. at 70.

2205 Pound, op. cit. supra note 59, at 128, I84.

200 In re Harrington Motor Co., Ltd., sikpra note 35 , at III, 59 A. L. R. at III4.

${ }^{22}$ Supra note III, at 67, 29 REV. LEG. (N. S.) at 95. . 
to sustain the validity of accident insurance in the life of another by the argument that it increases the ability of the assured to pay. ${ }^{228}$ If the assured does not in fact pay the assets of the policy or their equivalent, it is a specious argument that sanctions the appropriation of the benefits of the policy by the cupidity of the assured and his general creditors at the expense of the assured's victim.

Another reason for requiring the victim to share with the creditors the blood money, is that the assured does not need to pay his injured victim the actual assets of the policy; it would satisfy the law, if he paid the injured person the equivalent, out of any resources he may have. ${ }^{229}$ The assignee of an insolvent assured is trustee for his creditors. ${ }^{230}$ In $R e$ Harrington Motor Co., Ltd., a recent English case, all the judges of a court of equity deplored the necessity of sacrificing the victim, while they distributed the proceeds of the bankrupt's indemnity policy equally among the assured's creditors. ${ }^{231}$ They deluded only themselves when they said they could not avoid it. To say that the assets of an accident policy, when the victim of the accident has not been paid for his injuries, is a general asset of the assured's estate, is to profane the law and to make human parasites out of creditors. A promise to pay the debt of another is a valuable right of the debtor which can not be taken on execution against a promisee ;32 but a promise to indemnify against injuries from accident suffered by an innocent victim has to be deemed a general asset of the assured and must be distributed among all creditors. Such a result values property more highly than life and is so contrary to the common sense of sensible people as to shock their sense of decency. Yet, this was the issue in Bain $v$. Atkins, but the Massachusetts court repudiated the contention of counsel because in its essence it made the assets of the policy "a trust fund for the payment" of the assured's victim. Such a contention seemed so absurd to the court, it was considered groundless. ${ }^{233}$

When a mortgagor covenants to insure the mortgaged premises for the benefit of the mortgagee, he may not profit by his wrong if he breaches his covenant. Not to give him an equitable lien would be a violation of the first principles of equity. ${ }^{234}$ Is the duty imposed by a covenant any greater than the duty of a wrongdoer not to profit by the injury which he inflicts

${ }^{23}$ American Casualty Ins. Company's Case, 82 Md. 535, 576, 34 Atl. 778, 785 (I896); Messersmith v. Am. Fidelity Co., 232 N. Y. 16I, 164, I33 N. E. 432, 433 (1921). The fallacy had its origin in the erroneous deduction from the passage quoted. See supra note 83 .

${ }_{20}$ Sipra note 35 , at II8, 59 A. L. R. at III8.

200 Bankruptcy or insolvency of insured as affecting right of person injured to proceeds of indemnity insurance in absence of provision in policy in that regard, Note (I929) $59 \mathrm{~A}$. I.

R. II23, II24.

Sus Supra note 35 , at 127,59 A. L. R. at II24.

$2 s$ WuLISTON, CoNTRACTS, $\$ 362$; Williston, op. cit. supra note 66,776 . at 72

$\approx$ Supra note 28 , at 243,63 N. E. at 415 . Cited with approval by Rhodes, supra note 80 ,

₹34 Ames v. Richardson, 29 Minn. 330, 13 N. W. 137 (1882). 
upon another? The difference lies in the magic of the word "privity". Two states, by statute protect the insurance on the life of the assignor from the cupidity of creditors. ${ }^{235}$ Common decency ought to preserve to an injured victim the assets by which the estate of the assured is enriched by the injury which he inflicts. When the English court of equity recently refused to distinguish it from general assets, by making an exception of an accident indemnity policy as an asset, it expressed the hope that the law would be altered by legislation. ${ }^{236}$ Proposals have been made in the House of Commons to make the insurance company trustee of the proceeds for the injured person. ${ }^{237}$ In I9I4, Massachusetts enacted a statute, which gave to the injured party a lien on the assured's policy of indemnity which a "no action" clause could not defeat. ${ }^{238}$ But, in 1925, the Massachusetts court held that, even though the judgment of the injured party had not been paid, the assured could recover the assets of a policy. The theory of the court was that the statute gave the injured party a temporary lien upon the insurance money, if he desired to use it, but that did not prevent the insured from recovering on the policy without paying the judgment. In other words the assured could divest the lien of the injured party on the proceeds of the policy by action upon it. 239 The quarter of a century which has elapsed since its decision in Bain v. Atkins does not seem to have intensified the appreciation of the Massachusetts court of the problem by which it was confronted nor to have clarified its comprehension of its difficulties. Under the guise of logic, the dogma of a medirval ghost still ruled it from the mists of antiquity, despite the social consequences. ${ }^{240}$

\section{Unsophisticated Practices of the Insurer}

In a Washington case, ${ }^{241}$ the assured was protected by a $\$ 5000$ accident policy. The plaintiff, who was injured through the negligence of the assured in the operation of his automobile, recovered a judgment against him for $\$ 4325$, which the assured was unable to satisfy because he had no property. Two days before the action was begun by the plaintiff, the insurer gave $\$ 850$ to the assured to cancel the policy. The insurer thought it had made $\$ 4 \mathrm{I} 50$ by the cancellation. Of course, although there was no privity between the insurer and the injured party, where the policy was made for the benefit of the injured party, the insurer could not avoid liability

235 CAI Crv. Code (Kerr, I920) \$3470; Hawkins v. McCalla, 95 Ga. 192, 193, 22 S. E. I4I, I42 (I894).

${ }^{200}$ Supro note 35 , at II6, 59 A. L. R. at III7.

207 Third Party Insurance (I929) I68 L. T. 400.

238 Lorando v. Gethro, 228 Mass. I8I, 186, II7 N. E. 185, 187 (I9I7).

20 Lunt v. Aetna Ins. Co., 253 Mass $_{4} 610,612$, I49 N. E. 660, 66I (I925).

${ }^{200}$ Oliphant \& Hewitt's Introduction to Ruefr, From tHe Paysical to the Soctar ScIENCES (I929) XXvii.

su Finkelberg v. Continental Casualty Co., 126 Wash. 543, 219 Pac. I2 (Ig23). 
that way. In a Tennessee case, ${ }^{242}$ the assured employer got $\$ 50$ in settlement of all liability of the insurer on a policy, although the employee was unable to collect a $\$ 1000$ judgment against the assured for his injuries. The assured only made a profit of $\$ 50$ by his negligence, because he had not given the required notice. Equity approved the settlement which enriched the wrongdoer. There was no fraud because there was no privity between the injured party and the insurer. In a Virginia case, ${ }^{243}$ the insurer settled a $\$ 5732$ liability with the assured for $\$ 2000$, but the insurer was so slow in making the settlement with the execution-proof assured, that the assured made only $\$ 2000$ and the insurer only $\$ 1732$ because it had to pay an additional $\$ 2000$, the amount of the settlement. Equity affords no hope for the injured employee, where the insurer settles with the insolvent employer, even though both profit by the settlement. ${ }^{244}$ Because of privity, the employer does not insure for the benefit of the employee; he insures only for his own enrichment. Why should an employee complain in a court of equity if the insurer makes his judgment for damages due to personal injuries valueless by making a good settlement with the employer? The insurer's liability was to the employer, who had an insurable interest in the life of the employee. If the employer merely negligently killed him, the insurer should settle with the employer for the law of privity so prescribes. Moreover, the employer was not bound to insure against negligently disposing of his employees that way. If the assured is insolvent; the insurer argues that it ought not to be required to pay because there is no loss ${ }^{245}$ _but if it wishes to enrich the assured by a voluntary settlement of its liability, the law ought not to curb its freedom of settlement by denying that privilege. Doubtless, the insurer has often suffered from the lack of scrupulosity of the "ambulance-chasing" lawyers, ${ }^{246}$ but it has seldom been with the aid of the courts. When courts encourage insurance which brings insurer and assured in privity and then because of privity allow both to profit at the expense of the victim of the negligence of the assured, they must perceive their judicial tasks with a vision, obscured by formalism and unguided by the imagination. ${ }^{247}$

In a Missouri case, ${ }^{248}$ the insurer advised the assured employer to circumvent the payment of the judgment of the injured employee by fraudulently running the business in the name of one of its stockholders. In a Kansas case, ${ }^{249}$ a physician, who had an earning power of $\$ 4000$ and was

212 Finley v. United States Casualty Co., Ir3 Tenn. 592, 83 S. W. 2 (1904).

${ }^{213}$ Combs v. Hunt, supra note 105 .

su Owens v. Jackson-Hinton Gin Co., 217 S. W. 762, 764 (Tex. Civ. App. I920).

2us Herbo-Phosa Co. v. Philadelphia Casualty Co., supra note 166, at 572, 84 At1. at I095.

24s Reid, Casualty Instirance (I928) AM. YEAR BOoK 365, 366.

${ }_{2 \pi}$ Cardozo, Law and the University (I93I) 47 L. 'Q. REv. I9.

213 Hoagland Wagon Co. v. London Guar. \& Acc. Co., supra note I7I, at 499, 2I2 S. W. at 397. See also Melukhova v. Employers' Liability Assur. Co., sibpra note II2, at 6r4, 63 Can. S. C. R. at 520 .

${ }^{210}$ Emerson v. Western Auto Indemnity Ass'n, supra note ro8. 
protected by a $\$ 2500$ accident policy, went into voluntary bankruptcy to avoid liability on the policy after a judgment for $\$ 2500$ had been secured against him. The insurer's attorneys represented the assured in the bankruptcy proceedings. In New York, after the insurer had represented to the tax commission that its policy afforded the protection required by the statute, in an action on the policy of insurance, it denied that the policy could be so construed. ${ }^{250}$ The state superintendent of insurance of New York recommended certain legislation:

“. . . in order to eliminate evil, which was becoming a general practice among insurance companies: $i$. e., the practice on the part of insurance companies with assureds . . . to put the assured through bankruptcy, thereby precluding a recovery on the part of the injured by reason of the fact that an execution against the assured would be returned unsatisfied and the company then standing on a technical construction of the policy could claim, that, since it was an indemnity policy for loss occasioned to the assured, the assured having sustained no loss, there was nothing which the company could be legally called upon to pay." 251

The shortsightedness of the courts gave currency to such collusion. The courts might easily have realized the result the statute accomplished, by forestalling the defeat of the rights of the injured victim by an adjudication in bankruptcy of the assured and have prevented the injustice which has so frequently outraged common sense. When the United States Supreme Court upheld the constitutionality of the New York statute, Chief Justice Taft said: ${ }^{252}$

"the legislature might have required that policies of this kind should subrogate one injured and recovering judgment against the assured to the right of the latter to sue the company on the policy. It would simply create a secured interest in the recovery on the policy for the benefit of the injured person when ascertained."

Indeed, without a statute, the injured person might have been subrogated to the rights of the assured on condition that he discharge his judgment to the extent of the value of the policy; or the assured might have been compelled to assign the policy to the injured victim in satisfaction of the judgment to the extent of the value of the policy; or if it could have been reached by execution or attachment, it might have been seized and sold to satisfy the judgment. Clear thinking, guided by a sense of justice, should have enabled the courts to do what Chief Justice Taft said the legislature

${ }^{200}$ Devlin v. New York Mutual Casualty Taxicab Ins. Co., I23 Misc. 784, 787, 206 N. Y. Supp. 365, 368 (Ig24).

Roth v. National Auto. Mutual Casualty Co., 202 App. Div. 667, 669, 195 N. Y. Supp. 865,867 (I922).

Merchants Mutual Auto. Liability Ins. Co. v. Smart, 267 U. S. 126, I31, 45 Sup. Ct. 320, 321 (1925). 
might do; a'quarter of century before he said it. 'Had the courts recognized their opportunity, there would have been no incentive for the insurers to call the policies "liability" policies when they sold them ${ }^{253}$ and "indemnity" policies when they were asked to pay them; nor would the insurers have been tempted to escape liability, after agreeing with the em-ployer to defend at its own cost, by not giving a bond on appeal from an adverse decision. ${ }^{254}$

\section{Workmen's Compensation}

The vicious influence of the artificial distinction between "liability" and "loss" has nullified in part the benefit of workmen's compensation acts. According to Bradbury, in I9I7, most of the policies taken out by employers contained the "no action" clause. ${ }^{255}$ When the employer became insolvent, or bankrupt, so that he could not pay the judgment for damages, rendered on account of the injury or death of the employee, the insurer entirely escaped liability. With judicial sanction, ill-conceived, the insurance companies almost universally took advantage of the situation whenever possible. By statute, in some states, the insurer was required to assume a direct liability to the injured employee. ${ }^{256}$ Even today, a small minority of the states seem to give adequate protection to the injured employee by securing to him the assets of his employer's insurance policy. ${ }^{257}$ In California ${ }^{258}$ and Minnesota, ${ }^{259}$ the employee has a lien on the policy. Indeed, without a statute, he always had a primary interest in the assets of the policy, Bain v. Atkins to the contrary notwithstanding. In at least two.states, the industrial commission or commissioner of labor may enforce the policy for the benefit of the employee. ${ }^{200}$ As recently as I922, the United States Bureau of Labor Statistics reported as a result of state investigations that the profits of the insurer made by "short-changing" practice amounted to millions of dollars annually. ${ }^{261}$ Under any scheme of accident indemnity against injury, the

$\approx 3$ Blanton v. Cotton Mills Co., supra note 45 , at 123,172 Pac. at 989.

z Staggs v. Gotham Mining Co.; Most v. Massachusetts Bonding \& Ins. Co., both supra note 93 .

${ }_{253}^{93}$ BRADBURY, WorkMEN's Compensatton (3d ed. IgI7) in63.

250 Ibid. II74.

$\approx$ CAL. GEN. LAWS (Hening, I920) Act 2781, §30 (b) ; IdaHo Comp. Stat. (I9I9) \$6282; Mv. ANn. Codg (Bagby, I924) Art. IOI, \$30; Mich. CoMP. LAws (1929) $\$ 846 \mathrm{I}$ (2); N. Y. ANN. Cons. Laws (Cahill, r930) c. 66, § 54 ; UTAH CoMp. Laws (I9I7) \$3I16; WIS. STAT. (1929) § 102.30. See also The Cascade, 24I Fed. 206 (E. D. N. Y. 1916); United States Fid. \& Guar. Co. v. Indiana Acc. Com., I95 Cal. 577, 234 Pac. 369 (I925); Matter of Aioss v. Sardo, 249 N. Y. 270, I64 N. E. 48 (r928); Fidelity \& Cas. Co. v. House, I9I S. W. I55 (Tex.' Civ. App. I9I7). See also 2 Schnerder, WorkMEN's CoMpensation LAW (I922) \& 48r.

CAL. GEN. LAwS, supra note 257, at $\$ 30$ (d).

200 MinN. Stat. (Mason, I927) \$ 4289.

$200 \mathrm{MD}$. ANN. CoDE, stupra note 257 , at $\$$ 29-3I; N. Y. ANN. CoNs. LAws, supra note 257. In Ohio, all judgments obtained in any action prosecuted by the board or state under the act shall have the same preference as judgments rendered on a claim for taxes. OHIo GEN. CODE (Throckmorton, I930) \& I465-77.

am Comparison OF WORKMEn's CoMpensation Insurance and Administraton (1922), Bulletin No. 3or, Bureau of Labor Statistics, I5. 
securing of compensation to the injured is, and always has been, from a social point of view, the dominant consideration. ${ }^{262}$ The legal test of the right of security of the individual to his physical integrity is the same for every citizen, whether he is an employee under workmen's compensation or merely an unoffending pedestrian. Befogging obscurity in the judicial mind, induced by privity, does not palliate the evil of permitting either the insurer or the assured to profit by their traffic in human life, regardless of its particular status, be it in a humble or in an exalted station, if an efficient administration of justice is to obtain.

\section{Modern Legislation}

Because of the remarkable growth of accident insurance in the last decade, ${ }^{\mathbf{2 6 3}}$ it is not surprising that in many states, unusual activity has been manifested in an attempt, not only to secure financial liability of negligent operators of automobiles, ${ }^{264}$ but also to nullify the privity-induced folly of those judicial decisions which declared that the property interest of the assured and his creditors far outweighs the interest of society in securing to the maimed and his dependents compensation for the wrong negligently inflicted upon him, by securing to him the assets of the policy, the existence of which depended upon his life, and liability under which depended upon his injury. Much of this legislation represents merely a statutory repeal of "the narrowly limited legal science, indifferent to, even intolerant of light from without" which those decisions embodied. ${ }^{265}$ In 1925 , when the validity of compulsory automobile insurance was doubted, the Massachusetts court discovered that the business of accident indemnity was of such a peculiar nature and so intimately connected with general welfare that the constitution permitted the accident- policy to be enforced for the benefit of the victim of the assured's negligence. ${ }^{206}$ This discovery was very remarkable, in the light of the fact that, in 1902, the Massachusetts court thought it was absurd to even argue that the injured party had any equitable right to the assets of such a policy. Of course, it does not seem so absurd when one learns that of all the accident policy premiums paid by 30 per cent. of the owners of automobiles, who are insured, ${ }^{267}$ only from 25 per cent. to 30 per cent. of the premiums for such insurance ever reaches the victims of the accidents. ${ }^{268}$ According to Dean Pound, the law does not create interests; it merely recognizes them. In 1925, the Massachusetts court merely recognized what it ignored, under the camouflage of privity, in I902.

${ }^{202}$ Ibid. 18.

Reid, Casualty and Miscellaneous Insurance (I926) AM. YEAR BoOK 483.

20 Reid, Casualty and Miscellaneous Insurance (1927) AM. ŸEAR Book 337, 338, (1929)

AM. YEAR BOOK 355,357 .

${ }^{205}$ POUND, INTERPRETATIONS OF Legat History (1923) 46.

200 Opinion of Justices, 25I Mass. 569, 607, I47 N. E. 681, 698 (1925).

$20 \pi$ Ibid. 594.

$=0$ Marx, supra note 24, at 188. 
I. Indemnity bonds required from inotor carriers for hire. Legislation requiring indemnity bonds from all motor carriers for hire has become a common guaranty to insure the financial responsibility of the carrier. ${ }^{260}$ These statutes were enacted for the benefit of persons who were injured by the operation of the vehicles, ${ }^{270^{\circ}}$ although some argue that it was only for the benefit of the traveling public. ${ }^{271}$ The statutes are generally sufficiently broad to cover all cases of injury to pedestrians as well as to passengers. ${ }^{272}$ They transcend the limitations of privity. ${ }^{273}$ Nor is the insurer or the assured readily able to denude himself of liability to the injured ${ }^{274}$ for the courts now recognize the injured victims as the real parties in interest, whose rights can not be evaded on technical grounds. ${ }^{275}$

2. Insurer not relieved by bankruptcy or insolvency of assured. When the insurer could evade all liability, with the approval of the majority of courts, by the bankruptcy of the assured, it was an incentive to the insurer to profit by the specious philosophy of the courts that an insolvent can suffer no loss when he can not pay. To avoid the senseless result at which the courts arrived, by disregarding the policy as an asset of the assured when he is insolvent, statutes have been enacted in a few states within the last ten years which provide that the insolvency or bankruptcy of the assured shall not release the insurer from any payment for which it would otherwise be liable under the policy.276 These statutes have nullified the vice of many ill-considered decisions. In some states, the workmen's compensation acts include such a provision precluding the release of the insurer from liability on account of insolvency or bankruptcy of the assured. ${ }^{2 \pi 7}$ It is particularly interesting to note that, after nearly two decades Wisconsin repealed, by legislation, ${ }^{278}$ the judicial fallacy of the Stenbom Case, in part at least.

200 Ibid. 172.

270 VANCE, op. cit. supra note 20,682, n. 82 .

$2 \pi$ COOLEY, op. cit. supra note 16 , at 6320 .

20 AIA. CIV. CoDE (I928) \$6270 (5); Smith Stage Co. v. Eckert, supra note 23, at 34, I84 Pac. at I003; Malachowski v. Varro, 76 Cal. App. 207, 210, 213, 244 Pac. 936, 937, 938 (I926); Gillard v. Manufacturers Casualty Ins. Co., 92 N. J. L. I4I, I04 At1. 707, I07 At1. 709 (I918); Devoto v. United Auto. Trans. Co., I28 Wash. 604, 607, 223 Pac. 1050, I05I (I924) ; Ehlers v. Automobile Liability Co., I66-Wis. I85, 187, I64 N.' W. 845, 846 (I9I7). ${ }_{20}$ Stusser v. Mutual Union Ins. Co., I27 Wash. 449, 456, 221 Pac. 331, 333 (I923).

27t United States Fid. \& Guar. Co. v. Allen, 158 Tenn. 504, 508, I4 S. W. (2d) 724, 725 (Ig29).

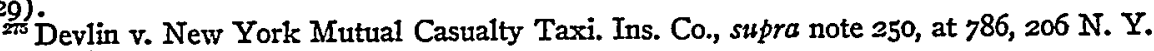
Supp. at $36 \%$.

M78 Marple v. American Auto. Co., 82 Cal. App. I37, 255 Pac. 260 (1927) ; Levy v. Superior Court of San Francisco, 74 Cal. App. I7I, 239 Pac. r100 (1925); Shea v. United States Fidelity Co., 98 Conn. 447, 453, I20 At1. 286, 288 (I923) ; CuMr. SUPP. zo N. J. CoMp. STAT. (I9II-24) § 99-90e; Miller v. Union Indemnity Co., 209 App. Div. 455, 204 N. Y. Supp. 730 (I924) ; Indemnity Ins. Co. v. Davis' Adm'r, I50 Va. 778, I43 S. E. 328 (I928); Ducommun v. Inter-State Exchange, 193 Wis. 179,212 N. W. 289 (1927). See also New Jersey Fid. \& Plate Glass Ins. Co. v. Clark, 33 F. (2d) 235 (C. C. A. 9th, Ig29); Eagle Indemnity Co. v. Diehl, 27 F. (2d) 76 (C. C. A. 9th, 1928).

Minn. Stat., supra note $259 ;$ N. Y. ANn. Cons: LAws, supra note 257 ; UTA Comp.

LAws, supra note 257 , at $\$ 3118$.

sis WIS. STAT. (I925) \& 204.30. 
In I9I4, Massachusetts enacted a statute ${ }^{27 \%}$ by which the liability of the insurer became absolute under any policy of insurance against loss on account of bodily injury or death by accident. Satisfaction of the judgment by the assured was not necessary to enable recovery on the policy. In an action on the policy, this statute, which has been copied in other states, ${ }^{280}$ made the question of the assured's insolvency irrelevant. Its object was to protect the beneficial interest of the person injured.

3. Injured victim given right of action on policy. Under the workmen's compensation acts, many states gave the injured employee a direct action against the insurer to recover his compensation. ${ }^{281}$ In Rhode Island ${ }^{282}$ and Wisconsin, ${ }^{283}$ the insurer is made directly liable to the injured party in all accident policies. The insurer may be joined with the assured in the original action by the injured party. ${ }^{284}$ In Oregon, if the judgment against the assured is not paid within thirty days, the injured party may proceed against the insurer to collect it. ${ }^{285}$ Such a provision seems superior to the insolvency clause inserted in some statutes because no dispute can arise as to when a person is insolvent. ${ }^{286}$

4. Agreement to cancel policy forbidden. Under the Massachusetts statute of I9I4, the legislature forbade the insurer to cancel or annul the policy by any agreement with the assured after he had become responsible for any damage, covered by the policy. ${ }^{287}$ This provision was declared to be not a dominant provision of the act, but only ancillary to its main purpose. $^{288}$ At any rate, it was intended to remedy a scandalous practice by the insurer to profit by defeating the right of the injured victim, although it seemed so often an innocent practice to the courts which wooed privity so ardently. The provision is to be found prevailing in those states which

${ }^{2 \pi}$ MASS. GEN. LAWS (I92I) c. I75, § II2.

- 90 ALA. Crv, Code (1928) \$8376; Conn. Gen. STat. (1930) §423I; OHio Gen. Code (Page, 1926) §9510-3. See also Federal Auto. Ins. Co. v. Abrams, 217 Ála. 539, II7 So. 85 (I928); Guerin v. Indemnity Ins. Co., I07 Conn. 649, I42 Atl. 268 (1928); New Amsterdam Casualty Co. v. Nadler, II 5 Ohio St. 472,476, I54 N. E. 736, 737 (1926).

231 BRADBURY, op. cit. supra note 255 .

25 R. I. GEN. LAwS (1923) \& 3815. Seq also Dillon v. Mark, 43 R. I. Irg, Iro Atl. 6 II (I920); Morrell v. Lalonde, 44 R. I. 20, II4 Atl. I78 (I92I) ; Indemnity Co. v. Davis' Adm'r, supra note 276.

2s3 WIS. STAT. (I927) \$ 85.25.

${ }^{234}$ Biller v. Meyer, 33 F. (2d) 440 (C. C. A. 7th, I929); Burkhart v. Burkhart, 200 Wis. 628, 229 N. W. 34 (I930); Morgan v. Hunt, 196 Wis. 298,220 N. W. 224 (I928); Ducommun v. Inter-State Exchange, supra note 276 ; White v. Kane, I79 Wis. 478 , 192 N. W. 57 (1923). See also Gugliemetti v. Graham, 50 Cal. App. 268, I95 Pac. 64 (1920); Bell v. Weiner, 46 R. I. 478, 129 At1. 339 (I925); American Auto. Ins. Co. v. Struwe, 218 S. W. 534 (Tex. Civ. App. rg20).

${ }_{255} 3$ ORE. CODE (1930) \& 46-I43. See also Lorando v. Gethro, supra note 238 , at I83, II7 N. E. at 186.

${ }_{280}$ United States Fid. \& Guar. Co. v. Williams, 148 Md. 289, 303, I29 Atl. 660, 665 (I925) ; Gullo v. Commercial Casualty Ins. Co., 226 App. Div. 429, 43I, 235 N. Y. Supp. 584, 586 (1929) ; Miller v. Union Indemnity Co., supra note 276 , at 458,204 N. Y. Supp. at 732; Perlman v. Independence Indemnity Co., I34 Misc. 499, 235 N. Y. Supp. I94 (1929).

232 Supra note 279 .

${ }^{203}$ Lorando v. Gethro, supra note 238 , at I86, II7 N. E. at I87. 
copied the Massachusetts statute. ${ }^{289}$ Under workmen's compensation, an execution-proof Ohio employer surrendered his policy to his insurer for $\$ 1600$ in order to defeat the injured employee's $\$ 5000$ judgment. ${ }^{290}$ The attempt failed because the statute makes such settlements void. Since these provisions have been in force, an accident policy is no longer a snare for insured nor a barren hope to the injured.

A cursory review of the legislation, enacted in the last fifteen years, which was designed primarily to curb the parasitic practices in accident insurance is a sad commentary upon our courts. By judicial decision, the assured and the insurer preyed upon their victim, for whose injuries the one was responsible and by whose injuries both were often enriched. Recently, one opponent of compulsory automobile insurance denounced it because "There is no privity of contract between the parties to a motor vehicle compensation case". ${ }^{291}$ It took a quarter of a century of legislation to correct partially the evil of irrelevant privity, but its ghost still stalks abroad. Another opponent cries fanatically ${ }^{292}$ "The rising tide of socialism is upon (us)". Inspired by the fear of state insurance, they protest vigorously. ${ }^{203}$ For thirty years, "progressive underwriters" have soothed the public ear by the slogan "An injury prevented is a benefaction, an injury compensated is an apology". ${ }^{294}$ To be freed from the embarrassment of compensating injuries, for thirty years, the efforts of accident insurance companies have been directed against obviating the necessity of compensating accidents. We know the truth of what the insurance expert tells us when he says, "Better one accident prevented than ten compensated". That truth has a strong financial appeal to insurers as is evidenced by the many decisions, which tardy legislation is now demonstrating. The socialism now dominant in accident legislation is primarily an effective protest against the consequences of the crass individualism ${ }^{295}$ to which our courts gave currency.

\section{Conclusion}

Today, there is no doubt that the primary purpose of various types of statutes regulating accident insurance is to afford relief to the injured victim ${ }^{296}$ because there is a widespread belief that he is the person who should benefit by accident insurance. ${ }^{29 \tau}$ Much of that legislation has . been due,

250 Supra note 280 .

200 McGhee v. Casualty Co., I5 Ohio App. 457, 463 (I921).

${ }^{2 n}$ Lilly, A Brief Statement of Certain Points in Opposition to Compulsory Compensation Insurance for Motor Vehicle Accident (1930) I6 A. B. A. J. 756, 757.

Ives, supra note 26 , at $14 \mathrm{I}$.

$\approx$ Watch Massachusetts (1926) I23 Nation 392. See also, Compensation Insurance for Motorists (Jan. 8, 1927) 92 LiT. DiG. 68.

* Rhodes, supra note 80, at 80 . See also Barnum \& Stephenson, Fallacies of Compulsory Automobile Compensation (1925) 23 OHIo L. REv. 469, 470. For a criticism see Rubinow, Conflict of Public and Private Interests in the Field of Social Insurance (I93I) I54 Ann. Am. Acad. of Pol. \& Soc. Scr. ro8, i1o.

$\approx$ Hadley, Some Influences in Modern Philosophic Thought (Igr3) 54.

$\approx$ Supra note II, at II6.

207 Fanslau v. Federal Mutual Auto. Ins. Co., I94 Wis. 8, II, 215 N. W. 589, 590 (1927). 
however, not to any inability of the common law to achieve justice, but to the artful misconception of the courts that privity was a relevant consideration. Doubtless, the New Hampshire doctrine was based upon the spurious device of estoppel, but it had the merit of securing a just result. ${ }^{298}$ At least, it was untainted by the irrelevant doctrine of privity which left the jnjured party penniless and made collusion current. It violated neither one's sense of justice nor one's sense of honesty. Tested by its result, it has been vindicated by recent legislation; it needs no further justification. In the judicial struggle between the competing philosophies which underlie the two doctrines, form was of more than theoretical importance. In its result, the New Hampshire doctrine recognized the social bearing of private rights. Under the specious dominion of privity, it did not ignore the current ideas of fair play. When a liability can be converted into a loss by giving a note to liquidate a judgment that the assets of a policy may be made available to an injured party, to insist that the distinction between loss and liability is essentially sound is to allow a technical obstacle, primitive and archaic, to encumber living institutions with dead ideas. The curse of such incumbrance becomes patent by the increasing frequency with which the insurer sought to defeat the right of the injured party to have the assets of the policy appropriated in compensation for his injury, when to have it diverted, meant merely a traffic in his injuries, more brutal than slavery. To allow the assets of an accident policy to be appropriated by creditors generally, when the injured party has not been paid for his injuries, on the ground that both he and they were strangers to the contract, exalts form and violates common sense and common decency. To call the right of the injured party to an accident policy, where his life and limb are the subject of the transaction, merely a "derivative" right and therefore "secondary" is a legal pedantry that judicial decision does not dignify. ${ }^{299}$ Such judicial interpretation outlaws accident insurance when it relates to the physical integrity of third persons. When courts are guilty of adopting it, one may sense the wisdom of Juvenal's observation that intellectual error is the more culpable because of the rank of the persons who commit it. The course of judicial decision in the majority of the states would seem to impose upon the departments of insurance in many states, which still suffer from the evils of such judicial interpretation, the duty of recommending to the legislature adequate remedies, that the victims of accidents may no longer be victimized by accident indemnity insurance.

${ }^{\infty}$ Pound, Taught Law (IgI2) Pro. Ass'n AM. L. Schools 56.

${ }^{20} O$ p. cit. supra note $\mathrm{I} 6 \mathrm{I}$, at I38, where Mr. Justice Holmes says: "Learning, my learned brethren, is a very good thing. I should be the last to undervalue it, having done my share of quotation from the Year Books. But it is liable to lead us astray. The law, so far as it depends on learning, is indeed, as it has been called, the government of the living by the dead." 